
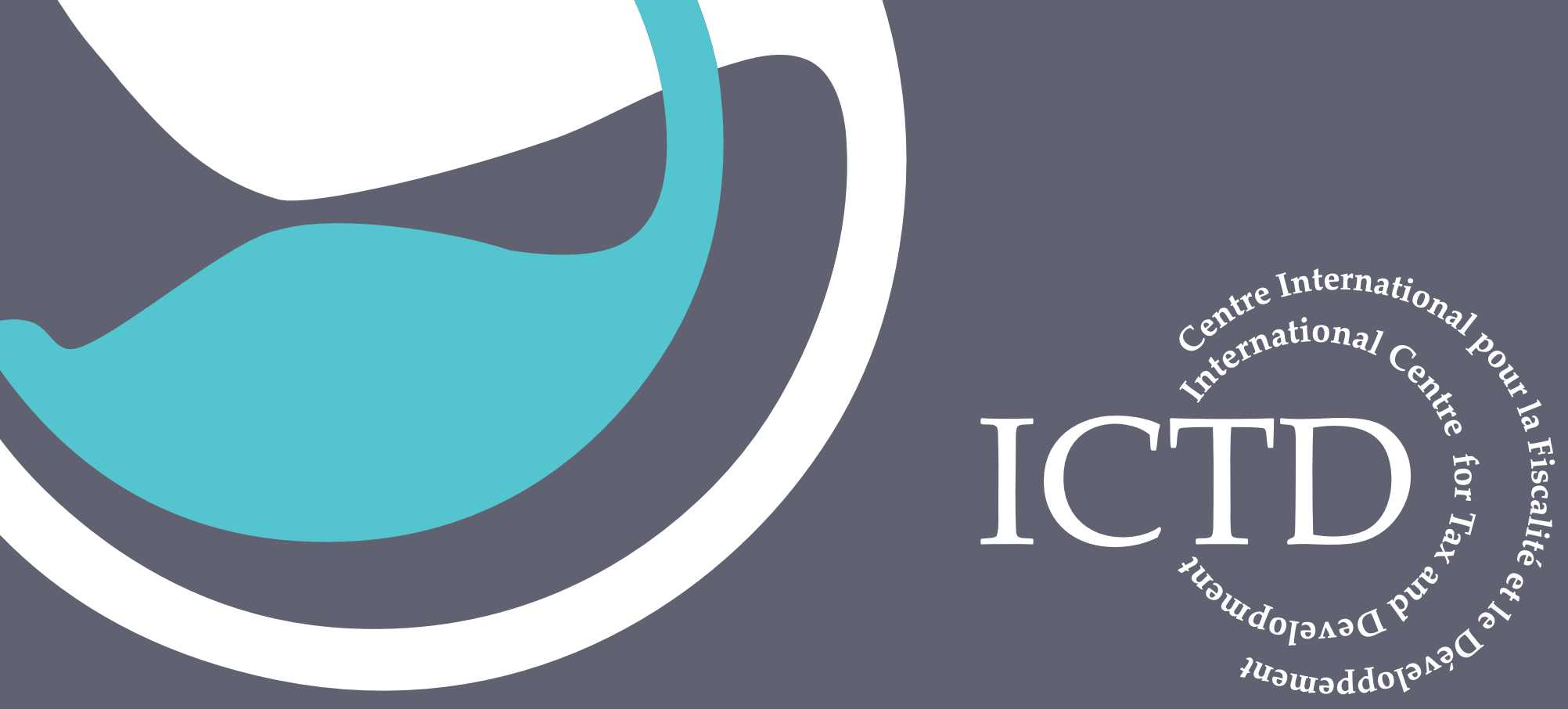

Working Paper 64

Irax Base Erosion and Profit Shifting in Affrica - Part 2: A Critique of Some Priority OECD Actions from an African Perspective

Annet Wanyana Oguttu

February 2017 
ICTD Working Paper 64

Tax Base Erosion and Profit Shifting in Africa Part 2: A Critique of Some Priority OECD Actions from an African Perspective

Annet Wanyana Oguttu

February 2017 
The International Centre for Tax and Development is a global policy research network that deals with the political economy of taxation policies and practices in relation to the poorer parts of the world. Its operational objectives are to generate and disseminate relevant knowledge to policymakers and to mobilise knowledge in ways that will widen and deepen public debate about taxation issues within poorer countries. Its ultimate objective is to contribute to development in the poorer parts of the world and help make taxation policies more conducive to pro-poor economic growth and good governance. The ICTD's research strategy and organisational structures are designed to bring about productive interaction between established experts and new stakeholders.

The ICTD is funded with UK aid from the UK Government, and by the Norwegian Agency for Development Cooperation (Norad), a directorate under the Norwegian Ministry of Foreign Affairs (MFA); however, the views expressed herein do not necessarily reflect the UK and Norwegian Governments' official policies.

Tax Base Erosion and Profit Shifting in Africa - Part 2: A Critique of Some Priority OECD Actions from an African Perspective Annet Wanyana Oguttu ICTD Working Paper 64

First published by the Institute of Development Studies in February 2017

(C) Institute of Development Studies 2017

ISBN: 978-1-78118-297-0

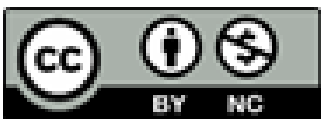

This is an Open Access paper distributed under the terms of the Creative Commons Attribution Non Commercial 4.0 International license, which permits downloading and sharing provided the original authors and source are credited - but the work is not used for commercial purposes. http://creativecommons.org/licenses/by-nc/4.0/legalcode

Readers are encouraged to quote and reproduce material from this series. In return, ICTD requests due acknowledgment and quotes to be referenced as above.

\section{Available from:}

The International Centre for Tax and Development

at the Institute of Development Studies, Brighton BN1 9RE, UK

Tel: +44 (0) 127360626

Email: info@ictd.ac.uk

Web: www.ictd/en/publications

IDS is a charitable company limited by guarantee and registered in England

Charity Registration Number 306371

Charitable Company Number 877338 


\title{
Tax Base Erosion and Profit Shifting in Africa - Part 2: A Critique of Some Priority OECD Actions from an African Perspective
}

\author{
Annet Wanyana Oguttu
}

\section{Summary}

In Part 2 of this article, the author continues her examination of the implications of the OECD's Action Plan on Tax Base Erosion and Profit Shifting from an African perspective. Although the OECD Project covers 15 Actions to address BEPS, the low economic development of many African countries, their limited administrative capacity and general lack of development of international tax laws limits the ability of these countries to fully implement all the OECD's recommendations to curtail BEPS. This paper identifies three of the highest priority actions that have the greatest BEPS impact for African economies. These are: Action 4 , which deals with limiting base erosion via interest deductions and other financial payments; Action 6, which deals with preventing treaty abuse; and Action 7, which deals with preventing the artificial avoidance of permanent establishment status. Referring to examples from an array of African countries, the paper discusses the special concerns that these countries face with respect to Actions 4, 6 and 7 and the limitations of the measures that they currently apply to deal with those concerns. Thereafter, the paper provides recommendations as to how African countries can effectively implement the OECD recommendations with respect to Actions 4, 6 and 7. This analysis is based on the premise that as much as African countries are encouraged to associate themselves with the OECD recommendations to curtail BEPS, their approach should be one of coming up with customised solutions to protect their tax bases. Since African countries' tax systems are not homogenous and since their levels of economic development as well as their levels of administrative capacity to deal with the challenges associated with BEPS vary immensely, each country must evaluate its own situation to identify its particular issues and determine the most appropriate techniques to ensure a sound tax base.

Keywords: Base erasing interest deductions; treaty shopping; treaty abuse; permanent establishment; base erosion and profit shifting; limitation of benefits; principle purpose test; beneficial ownership; thin capitalisation

Annet Wanyana Oguttu is a Professor of Taxation Law in the Department of Mercantile Law, College of Law, at the University of South Africa. She has published many articles on international tax law in national and internationally accredited journals. She is the author of 'International Tax Law: Offshore Tax Avoidance in South Africa' (Juta, 2015) and co-author of 'Tax Law: An Introduction' (Juta, 2013). She is a Commissioner of the South African Law Reform Commission, and a member of the Davis Tax Committee. 


\section{Contents}

Summary 3

Acknowledgements $\quad 5$

Acronyms $\quad 5$

$\begin{array}{ll}\text { Introduction } & 6\end{array}$

$1 \quad$ Action 4: Limit base erosion via interest deductions 8

$\begin{array}{lll}1.1 & \text { Measures applied by countries to curb excessive interest deductions } 9\end{array}$

1.2 OECD recommendations to curb BEPS from excessive interest deductions 12

1.3 General recommendations on curbing excessive interest deductions 13

$2 \quad$ Action 6: Prevent treaty abuse 14

2.1 Factors that encourage treaty abuse in Africa 14

2.2 Current measures to prevent treaty shopping 18

2.3 OECD BEPS recommendations on preventing treaty abuse 19

2.4 General recommendations to prevent abuse of tax treaties in Africa 24

$3 \quad$ Action 7: Prevent the artificial avoidance of PE status 25

3.1 Issues pertaining to preventing avoidance of PE status that are

3.1.1 Prevent avoidance of PE status through commissionaire arrangements 27

3.1.2 Splitting-up of contracts by contractors to circumvent
PE time limits

3.1.3 Splitting of service contracts to avoid PE status 38

3.1.4 Artificial avoidance of PE excluded activities 32

3.2 Issues pertaining to preventing avoidance of PE status that may be

of concern to developing countries but are not addressed by

the OECD BEPS project

3.2.1 Insurance

3.2.2 Abusing PE status - concerns about subsidiary 'entity isolation' 35

3.3 Preventing avoidance of PE status: Issues to be addressed post-2015 36

3.3.1 Artificial avoidance of PE status in the digital economy 37

3.3.2 Attribution of profits to PEs 37

3.3.3 General recommendations to prevent artificial avoidance of PE status

$4 \quad$ General conclusion $\quad 41$

$\begin{array}{ll}\text { References } & 43\end{array}$ 


\section{Acknowledgements}

This paper was presented at the International Bureau of Fiscal Documentation (IBFD) 1st African Tax Symposium in Zambia in June 2015 and subsequently published in the IBFD's Bulletin for Fiscal Documentation 2016, Volume 70, No. 6.

\section{Acronyms}

$\begin{array}{ll}\text { ATAF } & \text { African Tax Administration Forum } \\ \text { BEPS } & \text { Base erosion and profit shifting } \\ \text { CBTTC } & \text { Cross Border Taxation Technical Committee } \\ \text { CGT } & \text { Capital Gains Tax } \\ \text { DTA } & \text { Double taxation agreements } \\ \text { EBITDA } & \text { Earnings before interest, taxes, depreciation and amortisation } \\ \text { FDI } & \text { Foreign direct investment } \\ \text { IBFD } & \text { International Bureau of Fiscal Documentation } \\ \text { IMF } & \text { International Monetary Fund } \\ \text { IP } & \text { Intellectual property } \\ \text { LOB } & \text { Limitation of benefits } \\ \text { MNE } & \text { Multinational enterprise } \\ \text { OECD } & \text { Organisation for Economic Cooperation and Development } \\ \text { MTC } & \text { Model Tax Convention } \\ \text { PE } & \text { Permanent establishment } \\ \text { PPT } & \text { Principal purpose test } \\ \text { SARS } & \text { South African Revenue Services } \\ \text { TIEA } & \text { Tax Information Exchange Agreement } \\ \text { UN } & \text { United Nations } \\ \text { URA } & \text { Uganda Revenue Authority }\end{array}$




\section{Introduction}

In Part 1 (Oguttu 2016) of this two-part paper on base erosion and profit shifting (BEPS) ${ }^{1}$ in Africa, the author dealt with the question: 'What should Africa's response be to the OECD BEPS Action Plan?' In answering this question, the paper described what BEPS is, its causes and impact, and how African countries should response to the OECD BEPS project. The paper pointed out that although the OECD Project covers 15 Actions (OECD 2013a: 5) to address BEPS, the G20 Development Working Group on Domestic Resource Mobilisation for Developing Countries indicated that due to the specific challenges faced by developing countries, the highest priority actions that have the greatest impact for developing economies are (G20 2014):

- Action 4: Limit base erosion via interest deductions and other financial payments

- Action 6: Prevent treaty abuse

- Action 7: Prevent the artificial avoidance of PE [permanent establishment] status

- Action 10: Assure that transfer pricing outcomes are in line with value creation with respect to other high-risk transactions

- Action 11: Establish methodologies to collect and analyse data on BEPS and the actions to address it

- Action 13: Re-examine transfer pricing documentation.

The above are largely consistent with those identified by the United Nations (UN) Subcommittee on BEPS from the responses to its questionnaire about the priority BEPS concerns of developing countries (UN Committee of Experts 2014; UN 2015a: viii). It should be noted that the above Actions may not necessarily be of top priority in all African countries since they are at different levels of economic development and administrative capacity. Due to the broad nature of issues pertaining to each of these Actions, they cannot all be canvassed in an in-depth manner in an article with page limitations. This paper only deals with the first three of the priority actions from an African perspective (Actions 4, 6 and 7). This choice is informed by the Zambia's Tax Administration's response to the UN questionnaire on BEPS (the only African Tax Administration that responded to this questionnaire by the 2 May 2014 deadline). ${ }^{2}$ In response to the question: 'If you are affected by base erosion and profit shifting, what are the most common practices or structures used in your country or region?' Zambia's Tax Administration ${ }^{3}$ responded:

'The most common practices and structures include:

- tax treaty abuse especially through treaty shopping;

- profit shifting through high interest, royalty, management and consultancy fee deductions;

- the avoidance of permanent establishment creation by tailoring activities and contracts in such a way that the activities cannot be deemed/create a permanent establishment.'

These practices were also among those listed by the Economic Justice Network and Oxfam South Africa, a civil society organisation based in South Africa, which is the only other African entity that responded to the UN questionnaire. ${ }^{4}$ Although BEPS issues pertaining to

BEPS refers to 'tax avoidance' by multinational enterprises (MNEs) that use gaps in the interaction between different tax systems to reduce taxable income artificially, or shift profits to low-tax jurisdictions in which little or no economic activity is performed. See OECD 2013a: 5.

United Nations 'Questionnaire: Base erosion and profit shifting issues for developing countries', 2013, http://www.un.org/esa/ffd/tax/Beps/Bepslssues.pdf (accessed 25 November 2016).

3 UN 'Zambia's Tax Administration response to the BEPS questionnaire regarding country experiences with base erosion and profit shifting issues', http://www.un.org/esa/ffd/tax/Beps/CommentsZambia_BEPS.pdf (accessed 25 November 2016).

$4 \quad$ Economic Justice Network and Oxfam South Africa, 'Countries' experience regarding base erosion and profit shifting issues - South Africa', http://www.un.org/esa/ffd/tax/Beps/CommentsEJNandOxfamSA_BEPS.pdf (accessed 25 November 2016). 
transfer pricing are also of priority to African countries, due to page limitations, they are not covered in this paper.

In addressing the above mentioned action items, it is important to keep in mind that the package of measures to address BEPS (agreed upon by all OECD countries and OECD Associate countries - eight G20 countries which are non-OECD countries ${ }^{5}$ ) are designed to be implemented domestically and through treaty provisions, supported by targeted monitoring and strengthened transparency (OECD 2015a: para. 6). Since addressing BEPS is critical for all countries, the OECD consulted with developing countries and other nonOECD/non-G20 economies and their input was fed into the work (OECD 2014c: 3) to ensure a comprehensive approach which is globally supported. The OECD notes that international collaboration and co-ordination will not only facilitate and reinforce domestic actions to protect tax bases, but it is also key to providing comprehensive international solutions that may satisfactorily respond to the issues (OECD 2013a: 8). Thus African countries are encouraged to associate themselves with the OECD recommendations to curtail BEPS. The OECD's recommendations on implementing the BEPS measures fall under four main categories, which are set out below. The categories under which the priority action items discussed in this report fall are pointed out.

- The first category is the 'minimum standards' that were agreed upon to tackle BEPS issues, where no action by some countries would create negative spillovers on other countries. Action 6 , which deals with treaty abuse, falls under this category (OECD 2015a: para. 11). ${ }^{6}$

- The second category is the 'best practices and common approaches' which countries agreed on to address BEPS concerns, especially in a domestic context. These will facilitate convergence of national practices and in future could become minimum standards. Action 4, which deals with limiting base eroding interest expenses, falls under this category (OECD 2015a: para. 18). ${ }^{7}$

- The third category is 'guidelines to reinforce international tax standards' that countries agreed on. Action 7, which deals with curtailing artificial avoidance of permanent establishment status, falls under this category (OECD 2015a: para. 16). ${ }^{8}$

- The fourth category is 'analytical reports' under which fall: Action 1, dealing with the tax challenges of the digital economy; Action 11, on methodologies to collect and analyse data on BEPS; and Action 15, which deals with developing a multilateral instrument. Work on these analytical reports is still ongoing.

What follows below is a critical analysis of Africa's concerns with respect to Actions 4, 6 and 7 as well as recommendations as to how African countries can effectively implement the OECD recommendations in light of their economic development and tax administrative capacity constraints, as they endeavour to prevent BEPS. This analysis is premised on the view that Africa must come up with customised solutions to protect its own tax base. This is affirmed by the Cross Border Taxation Technical Committee (CBTTC) created by the African Tax Administration Forum (ATAF) ${ }^{9}$ in 2014 to define the African position on BEPS, to communicate the African response to the OECD/G20 BEPS project, and to present an African perspective on global tax matters. ATAF's CBTTC calls for a customised approach to addressing BEPS that will assist African countries and groups of countries in similar positions

5 OECD/G20 'BEPS Project: Information Brief - 2014 Deliverables', http://www.oecd.org/ctp/beps-2014-deliverablesinformation-brief.pdf (accessed 25 November 2016)

$6 \quad$ Other minimum standards cover: country-by-country reporting in Action 13; fighting harmful tax practices in Action 5; and improving dispute resolution in Action 14.

Other best practices are: neutralise hybrid mismatches - Action 2; building blocks of effective Controlled Foreign Company rules - Action 3; and mandatory disclosure by taxpayers of aggressive tax avoidance - Action 12.

Other best international tax standards cover Action 8-10 on transfer pricing, which has resulted in the revision of OECD Transfer Pricing Guidelines as well as aspects of Action 2 dealing with dual resident entities, which, along with Action 7 on PEs, will culminate in revisions of the OECD Model Tax Convention.

9 ATAF is an organisation that promotes and facilitates mutual cooperation among African tax administrators. For details on ATAF and its member countries visit http://www.ataftax.org/en/Pages/default.aspx (accessed 25 November 2016). 
to ensure domestic resource mobilisation (ATAF 2014). The UN has also stressed that efforts in international tax cooperation 'should fully take into account the different needs and capacities of all countries, in particular least developed countries, landlocked developing countries, small island developing States and African countries' (UN 2015b: para. 28). The following Africa-customised analysis of BEPS Actions 4,6 and 7 identifies the general concerns most African countries face and provides examples on specific matters from an array of African countries. It does not cover a detailed analysis of the issues in a specific African country.

\section{Action 4: Limit base erosion via interest deductions}

If a multinational enterprise (MNE) wants to finance its subsidiary companies in a group, it may do so by using loan capital, equity capital (Sommerhalder 1996: 80) or a combination of debt and equity capital (Lawrence 1990). Internationally, the tax treatment of a company and its finances differs fundamentally depending on whether it is financed by loan or equity capital (Sommerhalder 1996: 82). If capital is loaned by a parent company to its subsidiary, the latter will have to pay interest, which in most jurisdictions is a deductible expense in computing its taxable income (unless there are special rules to the contrary) (Oguttu 2013; Huxham and Haupt 2015: 80). If the parent company were to subscribe for shares in its subsidiary, dividends would have to be distributed by the subsidiary to the parent company. In most jurisdictions, dividends are not deductible when computing taxable income, since these are distributions of profits that have to be taxed (Sommerhalder 1996: 82). Clearly, financing a company with debt, at a deductible interest rate, is more effective in reducing source country tax than it is with equity financing, where dividends distributions are not deductible (Arnold and McIntyre 2002: 72-73; Olivier and Honiball 2011: 649). Indeed debt financing has long been recognised as a strong tax planning tool for MNEs which often come up with 'thin capitalisation' schemes to ensure that their subsidiary companies are financed with more debt than equity capital (Richardson, Hanlon and Nethercott 1998: 36). Although the availability of debt is essential for business growth, the potential for excessive interest deductions can erode countries' tax bases. Where debt is granted among related entities, and one is located outside the country of the interest payer, the interest payments can be a major risk for base erosion. Debt can be loaded into companies operating in high-tax countries and arrangements made for deductible interest payments to be received by an entity in a low-tax jurisdiction, where it may be taxed favourably or not at all (UN 2015a: 11). The OECD notes that 'the use of third party and related party interest is perhaps one of the most simple of the profit-shifting techniques available in international tax planning' (OECD 2015b: para. 1). This is because the fluidity and exchangeable nature of money makes it easy to adjust the mix of debt and equity capital in a controlled entity (OECD 2015b: para. 1). The BEPS risks that may arise with respect to excessive interest deductions often arise in three basic scenarios: firstly, subsidiary companies may be heavily debt financed, bearing a disproportionate share of the group's total third party interest cost and incurring interest deductions which are used to shelter local profits from tax (OECD 2015b: p.16). Secondly, parent companies can claim relief for their interest expenses, while the return on equity holdings is taxed on a preferential basis; for example if it qualifies for a participation exemption ${ }^{10}$ or a preferential tax rate (OECD 2015b: p.15). Thirdly, BEPS could also result through the use of interest deductions to fund income which is exempt or deferred for tax purposes, and obtaining relief for interest deductions greater than the actual net interest

10 A participation exemption can be defined as a tax regime under which dividends received from foreign companies by resident companies are exempt from resident country tax if the resident company owns at least some percentage of the shares of the foreign company. See Arnold and Mclntyre 2002: 165. 
expense of the group (OECD 2015b: p.16). These three scenarios can be employed in various strategies; for example, by using intragroup loans to generate deductible interest expense in high tax jurisdictions and taxable interest income in low tax jurisdictions. Another strategy is by developing hybrid instruments which can give rise to deductible interest expense but no corresponding taxable income. ${ }^{11}$ Another strategy is by using dual resident hybrid entities to claim double interest deduction in both jurisdictions. ${ }^{12}$

From a policy perspective, failure to tackle excessive interest payments to associated enterprises gives MNEs an advantage over domestic businesses that are unable to gain such tax advantages (OECD 2012: 7). Research shows that debt shifting is a major BEPS risk for developing countries and that they are more prone to these risks than developed countries (Fuest, Hebous and Riedel 2011: 12). The IMF affirms that debt shifting through intragroup loans is a common method of profit shifting that is of significant concern in many developing countries (IMF 2014: 30) which often lack effective provisions to guard against the use of borrowing to shift profits to lower tax jurisdictions (IMF 2014: 24). ATAF asserts that cross-border interest and similar financial flows to tax havens have a long track record in Africa as a BEPS risk. ${ }^{13}$ Many African countries are concerned about the high levels of interest deductions from their fiscus by domestic subsidiaries that are funded by foreign parent companies. ${ }^{14}$ Although countries may have general anti-avoidance provisions and judicial doctrines that may be applied to prevent the ensuring tax avoidance, the sophisticated interest deduction schemes that MNEs engage in often necessitate that countries enact more targeted provisions as discussed below.

\subsection{Measures applied by countries to curb excessive interest deductions}

The tax laws of countries cannot forbid enterprises from having excessive levels of debt but they can place limits on the amount of interest that is deductible. There are various measures that countries apply to curb excessive interest deductions (OECD 2015b: para. 6).

(a) The arm's length approach: Under this approach, the arm's length principle ${ }^{15}$ (which is applied in curbing transfer pricing ${ }^{16}$ ) is used to determine whether the size of the loan would have been made in an arm's length transaction ${ }^{17}$ or whether the rate of the interest is an arm's length rate (OECD 1987: para. 48). Thus, if the loan exceeds what would have been lent in an arm's length situation, then the lender must be taken to have an interest in the profitability of the enterprise and so the loan, or interest rate that exceeds the arm's length amount, is considered as designed to procure a share in the profits (OECD 2015b: p.12). Thus, a prima facie loan can be regarded as some other kind of payment; for example,

11 A hybrid instrument can be defined as a financial instrument which may be treated as debt in one country and yet be regarded as equity in another country. Hybrid instruments can be used to achieve double non-taxation by, for instance, creating two interest deductions for one borrowing; generating deductions without corresponding income inclusions; or misusing foreign tax credit and participation exemption regimes. See Oguttu 2012.

12 A hybrid entity is a legal relationship that is treated as a corporation in one jurisdiction and as a transparent (nontaxable) entity in another. Where a hybrid entity is dual resident, in that it is treated as a taxable entity in two jurisdictions (for example if it is incorporated in one jurisdiction and has its place of effective management in another), such an entity can be able to claim double interest deduction in both jurisdictions. See Arnold and Mclntyre 2002: 144; Olivier and Honiball 2011: 554; Oguttu 2009a: 51-73.

13 ATAF Second Meeting: Cross Border Taxation Technical Committee, 3-4 March 2015: 1; ATAF Workshop on Aggressive Tax Planning, 19-21 April 2016, Abuja, Nigeria, http://www.ataftax.org/en/Conferences/Pages/atp.aspx (accessed 16 December 2016)

$14 \quad$ ATAF Second Meeting: Cross Border Taxation Technical Committee (3-4 March 2015)

15 The arm's length principle as set out in Article 9(1) of the OECD Model Tax Convention (OECD MTC) provides that when conditions are made or imposed between two associated enterprises in their commercial or financial relations, which differ from those which would have been made between independent enterprises, then any profits which would but for those conditions, have accrued to one of the enterprises, but, by reason of those conditions, have not so accrued, may be included in the profits of that enterprise and taxed accordingly.

16 'Transfer pricing' is a term that describes the process by which related entities set prices at which they transfer goods or services between each other. It entails the systematic manipulation of prices in order to reduce profits or increase profits artificially or cause losses and avoid taxes in a specific country. See Arnold and McIntyre 2002: 53.

17 In an arm's length transaction, each party strives to get the utmost possible benefit from the transaction. See Article 9 of the OECD MTC, 2010 condensed version (OECD 2010). 
interest on a loan can be treated as a distribution of dividends for tax purposes (OECD 1987:15, para 25(i)). In Ghana, for instance, section 31(5)(a) of the Income Tax Act 896 of 2015 permits the Commissioner General to use the arm's length principle to re-characterise debt financing in a controlled relationship as equity financing. In South Africa, section 31 of the Income Tax Act 58 of 1962, as amended by the Taxation Laws Amendment Act 24 of 2011 , clearly provides that the arm's length principle has to be applied to financial assistance in cross-border transactions. Although the arm's length approach recognises that entities may have different levels of interest expense depending on their circumstances, it may not be effective in preventing BEPS in cases of groups structuring intragroup debt with equitylike features to justify interest payments that are in excess of those the group actually incurs on its third party debt (OECD 2015b: para. 12). The OECD also notes that the arm's length test is not effective in preventing an entity from claiming a deduction for interest expenses which is used to fund investments in non-taxable assets or exempt income (OECD 2015b: para. 12). It should also be noted that internationally there are no clear guidelines for determining the parameters within which the arm's length principle is to apply in the context of thin capitalisation (Oguttu 2013: 314). Consequently, countries tend not to only rely on the arm's length principle to curb thin capitalisation, but they often apply this principle alongside fixed debt/equity ratios (explained below).

(b) The fixed ratio approach: This approach, which is based on a fixed debt/equity ratio, is normally used as a 'safe harbour' in setting the parameters within which the arm's length principle applies. Under this approach, the interest relating to the debt above the fixed ratio is not deductible. ${ }^{18}$ Some countries apply fixed debt/equity ratios exclusively since they are considered relatively easier for tax administrations to administer as they can easily link the level of the interest expense to a measure of an entity's economic activity (OECD 2015b: para. 17). In Uganda, for instance, section 89 of the Income Tax Act, Cap 340, restricts the deduction of interest by a foreign-controlled resident company if 50 per cent or more of the resident company is held by a non-resident, where foreign debt to foreign equity ratio exceeds 2:1 (KPMG 2013: 13). Ghana's thin capitalisation rules in section 33 of the Income Tax Act 896 of 2015 provide that where a non-resident holds more than 50 per cent of a resident company, interest deduction in excess of a debt to equity ratio of $3: 1$ will be disallowed. Despite the presence of fixed ratio rules in some African countries, their revenue administrations still find it difficult to deal with excessive interest deductions, since generally the tax legislation does not clearly define the difference between what constitutes interest as opposed to equity. ${ }^{19}$ The OECD has over the years been supportive of the fixed ratio approach and it is open to assisting African countries in introducing rules that would be in line with international best practices. ${ }^{20}$ However, it cautions that fixed ratios can be relatively inflexible if the same ratio is applied to entities in all sectors. The other concern is that in some countries the rates at which these ratios are set are too high to be an effective tool in addressing BEPS, or too low, meaning that they can lead to double taxation risks. ${ }^{21} \mathrm{~A}$ rule which can limit the amount of debt in an entity can still allow significant flexibility in terms of the rate of interest that an entity may pay on that debt, which makes it relatively easy for a MNE to manipulate the outcome of a ratio by increasing the level of equity in a particular entity. Due to these disadvantages, the OECD advises that although the fixed ratio approach can play a role within the overall tax policy to limit interest deductions, in general it is not a best practice approach to tackle BEPS (OECD 2015b: para. 17).

(c) Withholding taxes: Some countries levy withholding taxes on interest as a means of preventing the erosion of their tax bases. A withholding tax is used as a mechanism to enable the collection of taxes from non-residents, by appointing a resident as the nonresident's agent and imposing an obligation on the resident agent to withhold a certain

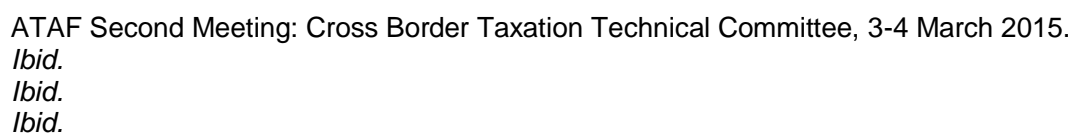


percentage of tax from payments made to the non-resident. If the resident agent does not comply with this duty or if he/she withholds an incorrect amount of tax, personal liability can be imposed on the resident agent (Olivier and Honiball 2011: 362-363). Many African countries levy withholding taxes on interest because this mechanism is considered a relatively mechanical tool which is easy to apply and administer (OECD 2015b: para. 13). In Uganda, for example, section 83(1) of Uganda's Income Tax Act, Cap 340 (subject to certain exemptions) levies a withholding tax of 15 per cent on gross interest payments to nonresidents from sources in Uganda. In Ghana's section 116 of Income Tax Act 896 of 2015, a withholding tax of 8 per cent is levied on interest paid to non-residents. In South Africa, (subject to certain exemptions) a withholding tax on interest is levied under sections $37 \mathrm{I}$ to $37 \mathrm{M}$ of the Income Tax Act 58 of 1962, at a rate of 15 per cent on interest received by or accrued by a non-resident from a South African source (De Koker 2016: para 14.4). Where there is a double tax treaty in place, withholding tax rates on interest are normally reduced to 10 per cent for double taxation agreements (DTAs) based on Article 11 of the OECD Model Tax Convention (OECD MTC). Any double taxation that arises is usually addressed in terms of Article 23A of the OECD MTC by giving credit in the country where the interest payment is received. In practice, however, interest withholding tax in most African countries' tax treaties is often reduced below 10 per cent (sometimes to zero) - which opens such treaties to abuse (OECD 2015b: para. 13). One would imagine that perhaps the best way to prevent base eroding excessive interest deductions is to set the withholding tax at the same rate as corporate tax; however this may hamper foreign investment (UN 2015a: 180). It should also be noted that lenders often minimise the impact of withholding taxes by 'grossing up' such payments so that the domestic company that borrowed the loan bears the cost of the withholding tax in the form of a higher interest charge (UN 2015a: 180). Since the high interest rate is a tax deductible expense in calculating tax income, this further reduces the borrower country's tax base. For the above reasons, the OECD advises that countries should apply withholding taxes alongside other best practices as discussed below (OECD 2015b: para. 13).

(d) Debt/EBITDA ratios: Some countries apply debt/EBITDA (Earnings before interest, taxes, depreciation and amortisation) ratios to prevent excessive interest deductions (OECD 2015b: para. 18). A debt/EBITDA ratio is a metric measure of a company's ability to pay off its short-term incurred debt by giving an investor the approximate amount of time that would be needed to pay off all debt. The metric ratio is calculated as debt divided by earnings, before factors such as interest, taxes, depreciation and amortisation (EBITDA) are taken into account. A high debt/EBITDA ratio suggests that a company may not be able to service its debt in an appropriate manner and can result in a lowered credit rating. Conversely, a low ratio can suggest that the company may want to take on more debt if needed and it often warrants a relatively high credit rating..$^{22}$ Although debt/EBITDA ratios may be useful, the fact that they do not include the effects of the company's expenditures on its finances requires that they should be used with caution when evaluating a company, as not all of the company's risk is accounted for in the ratio. ${ }^{23}$ For example, South Africa's Revenue Service (SARS) issued a draft interpretation note on thin capitalisation in 2013 (SARS 2013) in which it indicated that it has adopted a risk-based audit approach in selecting potential thin capitalisation cases for audit. In selecting cases, SARS will consider transactions in which the debt/EBITDA ratio of the South African taxpayer exceeds 3:1 to be of greater risk. SARS explains that the ratio is not a safe harbour and it does not preclude SARS from auditing a taxpayer who is within the range of the abovementioned ratio (SARS 2013: 3).

\footnotetext{
22 Investopedia, http://www.investopedia.com/terms/d/debt_edbitda.asp\#axzz2AxUfUVka (accessed 28 November 2016); see also 'Explanation of Debt to EBITDA Ratio, http://www.ehow.com/info_7856136_explanation-debt-ebitdaratio.html\#ixzz2AxWymT1e (accessed 28 November 2016).

23 The Free Dictionary, 'Debt/EBITDA ratio', at http://financial-dictionary.thefreedictionary.com/Debt\%2FEBITDA+ratio (accessed 28 November 2016).
} 
(e) Rules which compare the level of debt in an entity by reference to the corporate group's overall position: These group ratio tests typically operate by reference to debt/equity ratios. However in many cases the amount of equity in an entity may at best only be an indirect measure of its level of activity and can be subject to manipulation (OECD 2015b: para. 19).

(f) Targeted anti-avoidance rules: These rules disallow interest expenses on specific transactions. Unlike other African countries, South Africa's developed financial services sector has prompted the country to enact various targeted provisions in its Income Tax Act 58 of 1962 to prevented sophisticated interest deduction tax avoidance schemes:

- section $24 \mathrm{~J}$ regulates the incurral and accrual of interest in respect of financial instruments;

- section 45 deals with excessive debt transactions using debt pushdown structures in intragroup transactions;

- section $23 \mathrm{~N}$ limits the deduction of an interest expense incurred by a company on a loan or debt raised to acquire assets or shares in reorganisations and acquisition transactions;

- section 23M imposes a limitation on the deductibility of interest in debt owed to persons in a controlling relationship;

- section 240 limits the deduction of interest in respect of share acquisitions;

- section 10B deals with round-tripping;

- section $8 \mathrm{E}$ and $8 \mathrm{EA}$ deem a dividend declared by a company on a hybrid equity instrument as interest;

- section 8F and 8FA deem interest on a hybrid debt instrument to be a dividend in specie such that no deduction is allowed on the interest paid by the issuer of the instrument.

However, these numerous provisions have complicated the rules relating to cross-border debt which can discourage foreign investment especially for investors that are not involved in such sophisticated schemes. The downside of such provisions is that as new BEPS schemes are exploited, further targeted rules may be required and so there is a tendency over time for more rules to be introduced, resulting in a complex system and increased administration and compliance costs manipulation (OECD 2015b: para. 20).

\subsection{OECD recommendations to curb BEPS from excessive interest deductions}

When the OECD issued its BEPS Action Plan in 2013, Action 4 called on countries to come up with effective provisions that limit base erosion via interest deductions and other financial payments. In particular, they were called upon to develop rules that prevent the use of related-party and third-party debt to achieve excessive interest deductions as well as rules that prevent financing the production of exempt or deferred income (OECD 2013b: 17). The OECD evaluated the effectiveness of measures that countries apply to prevent base eroding excessive interest deductions and it concluded that the use of arm's length tests, withholding taxes and rules to disallow a percentage of interest are not effective (OECD 2014a: para. 21). ${ }^{24}$ The OECD recommends that countries should adopt a consistent approach of utilising international best practices if concerns regarding BEPS on interest deductions are to be addressed. Such a consistent approach would remove distortions, reduce the risk of unintended double taxation, remove opportunities for BEPS and as a result increase fairness and equality between groups (OECD 2014a: para. 5). ${ }^{25}$ Thus in its 2015 final BEPS Report on Action 4, the OECD recommends that the best approach to address BEPS is for countries to apply a fixed ratio rule which limits an entity's net deductions for interest and payments

\footnotetext{
24 OECD Discussion Draft 'BEPS Action 4: Interest Deductions and Other Financial Payments' (18 December 2014): para 21.

$25 \quad$ lbid. para 5.
} 
economically equivalent to interest to a percentage of its EBITDA and that this should apply to entities in multinational groups (OECD 2015b: paras. 23, 78, 99). To ensure that countries apply a fixed ratio that is low enough to tackle BEPS, while recognising that not all countries are in the same position, the OECD recommended an approach that includes a corridor of possible ratios of between 10 and 30 per cent (OECD 2015b: paras. 23, 78, 99). The OECD recognises that although the fixed ratio rule may provide a country with a level of protection against BEPS, it is a blunt tool which does not take into account the fact that groups operating in different sectors may require different amounts of leverage, and even groups within some sectors can be more highly leveraged for non-tax reasons (which could result in double taxation for groups which are leveraged above the level). Thus the OECD recommends that the use of a fixed ratio rule can be supplemented by a worldwide group ratio rule which allows an entity to exceed this limit in certain circumstances (OECD 2015b: paras. 24, 116). This would allow an entity with net interest expense above a country's fixed ratio to deduct interest up to the level of the net interest/EBITDA ratio of its worldwide group. Countries may also apply an uplift of up to 10 per cent to the group's net third party interest expense to prevent double taxation. The earnings-based worldwide group ratio rule can also be replaced by different group ratio rules, such as the 'equity escape' rule (which compares an entity's level of equity and assets to those held by its group). A country may also choose not to introduce any group ratio rule. In that case it should apply the fixed ratio rule to entities in multinational and domestic groups without improper discrimination (OECD 2015b: para. 119). The recommended approach also allows countries to supplement the fixed ratio rule and the group ratio rule with other provisions that reduce the impact of the rules on entities or situations which pose less BEPS risk, such as:

- A de minimis threshold which carves out entities which have a low level of net interest expense (OECD 2015b: paras. 1, 26).

- An exclusion for interest paid to third party lenders on loans used to fund public-benefit projects, subject to conditions. In these circumstances, an entity may be highly leveraged but, due to the nature of the projects and the close link to the public sector, the BEPS risk is reduced (OECD 2015b: 12).

- Provisions to permit carry forward of disallowed interest expense for use in future years. This will help entities which incur interest expenses on long-term investments that are expected to generate taxable income only in later years, and will allow entities with losses to claim interest deductions when they return to profit (OECD 2015b: 12).

Nevertheless, concerns have been raised that the recommendation for an interest rate cap within the band of ten and 30 per cent, with the option of using apportioned consolidated interest costs if they are higher, seems self-defeating in view of the fact that debt ratios vary widely both between economic sectors and firms. ${ }^{26}$ It has been suggested that a firm rule is needed that interest deductions should not be greater in aggregate than the corporate group's consolidated interest costs to third parties. It is also suggested that countries which insist on using a fixed cap on deductions should use the lowest limit (BEPS Monitoring Group 2015: 5).

\subsection{General recommendations on curbing excessive interest deductions}

As noted in paragraph 1.2 above, the OECD measures for curbing excessive interest deductions entail recommendations of best practices that are considered more effective in curtailing than in addressing the matter. For African countries, adopting appropriate measures to prevent base eroding of excessive interest deductions requires them to balance the need to attract foreign investment against the necessity of protecting the tax base. Numerous and complex targeted anti-avoidance provisions (as is the case with South Africa)

26 See the study by PwC included as an annex to the comments submitted by the Business and Industry Advisory Committee (BIAC) on Action 4, February 2015, http://biac.org/wp-content/uploads/2015/03/2015-Final-BIAC-commentsinterest-deductibility1.pdf (accessed 30 November 2016). 
may not be advantageous in this regard as they pose overwhelming administrative burdens and regulatory uncertainty. On the flipside, although the use of withholding taxes on interest may be considered easy to administer, high rates can also discourage foreign investment since they are normally levied on a gross basis.

\section{Action 6: Prevent treaty abuse}

Before discussing issues pertaining to treaty abuse, it is important to first provide some background as to how DTAs work. DTAs are normally drafted based on certain models. The two main models employed that are applied internationally are the OECD Model Convention on Income and on Capital, 2014 condensed version (OECD MTC) (OECD: 2014d) and the UN Model Tax Convention between Developed and Developing Countries (UN MTC) (UN: 2011). The OECD MTC embodies rules and proposals by developed capital exporting countries. It thus favours capital exporting countries over capital importing countries (Arnold and McIntyre 2002: 119). The UN MTC favours capital importing countries over capital exporting countries. One of the main reasons why countries entered into DTAs (Reinhold 2000) (as is found in the preamble of most DTAs) is to prevent double taxation. ${ }^{27}$ Some DTAs have in their preambles that the purpose of the treaty is to prevent double taxation and fiscal evasion (Oguttu 2015: 2). Currently the preambles of DTAs do not specify that they are not intended to be used for abusive tax avoidance practices. ${ }^{28}$ Nevertheless, although the network of DTAs that countries have entered into encourages international trade and investment, it also opens up opportunities to abuse treaties for tax avoidance purposes (Oguttu 2004: 242). Taxpayers may for instance get involved in 'treaty shopping', a term which refers to the use of DTAs by the residents of a non-treaty country in order to obtain treaty benefits that are not supposed to be available to them (van Weeghel 1998: 119). This is mainly done by interposing a 'conduit company' in one of the contracting states so as to shift profits out of those states (Wurm 1992 and Tomsett 1989: 149). A conduit company is an intermediary company with very narrow powers, which is used for holding assets or rights as an agent or nominee on behalf of another company (OECD Committee on Fiscal Affairs 1987 paras. 4.2 and 5(d) and Oguttu 2007: 238). Treaty shopping is however undesirable because it frustrates the spirit of a treaty (OECD Committee on Fiscal Affairs 1987 para. 4.2). The anticipated capital flows are distorted if the treaty is used by third country residents (Haug 1996).

\subsection{Factors that encourage treaty abuse in Africa}

(a) DTAs signed with low tax jurisdictions: As is the case with other countries, the DTAs that African countries have signed with low tax countries can be abused as part of sophisticated tax planning to frustrate the tax claims of African countries. Most treaty shopping schemes in Africa involve companies registered in Mauritius under the Global Business Licenses 1 regime (Rohatgi 2002: 284 and Oleynic 2006: 43), which encourages nil or minimum tax on active business in Mauritius while taking advantage of other countries' treaty benefits. Mauritius has historically been an established treaty haven for offshore activities from African countries. Its extensive tax treaty network, with African countries, and its membership of regional bodies such as the Southern African Development Community, ${ }^{29}$ offers African country tax residents the opportunity to route their investments via Mauritius

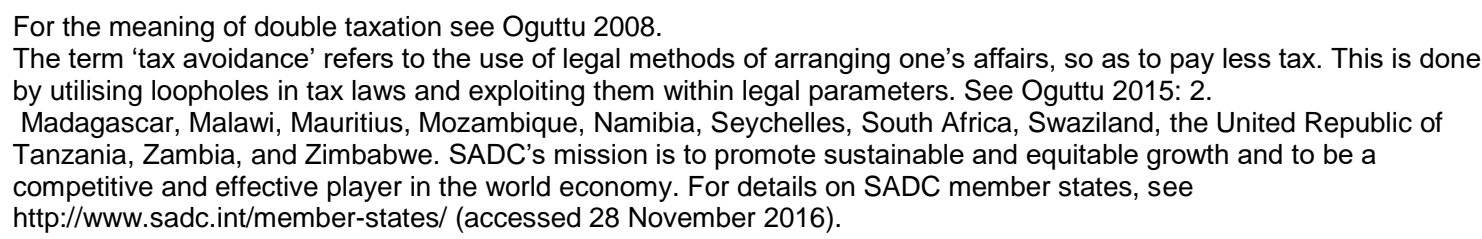


and for foreign investors, the opportunity to route their investments in Africa via Mauritius. ${ }^{30}$ Apart from Mauritius, African countries have also signed treaties with other low tax jurisdictions, such as the Netherlands and Switzerland, which have also raised treaty abuse concerns. The IMF estimates that treaties with the Netherlands led to foregone revenue for developing countries of at least $€ 770$ million in 2011 (IMF 2014: 22). Treaties signed with low tax jurisdictions encourage treaty abuse because of the following factors:

Low withholding taxes: Because the DTA negotiators of African countries are not as skilled as their developed country counterparts in negotiating DTAs (PwC and EuropeAid 2011:21), they often sign DTAs that contain provisions that are not in their favour but rather reflect the position of the other contracting state (Akunobera 2012: 1089). Of particular concern is the low or zero withholding tax rates for dividends, interest or management fees payable by MNEs, which are also often used for treaty shopping purposes. This was one of the main reasons why in 2013, Rwanda negotiated its 2001 DTA with Mauritius in which withholding taxes were at a zero rate, giving all taxation rights to Mauritius. The new DTA, which was ratified on 4 August 2014, provides a 10 per cent withholding tax on dividends, royalty and interest, and 12 per cent for management fees. ${ }^{31}$ Rwanda Revenue Authority notes that the new DTA is intended to stop treaty shopping, where investors would opt to register their companies in Mauritius while doing business in Rwanda, and repatriating all their profits without paying taxes. ${ }^{32}$ For this (and other reasons), in 2015, South Africa renegotiated its 1997 DTA with Mauritius. ${ }^{33}$ South African residents wishing to invest in India often took advantage of the old DTA by routing investments via Mauritius in order to gain tax advantages. South African companies also often route investments into other Africa countries via Mauritius because it has negotiated better benefits (such as lower withholding tax rates) in its tax treaties with some African countries than is the case with South Africa. It was also because of similar concerns that in October 2014, the Tax Justice Network instituted a case in the Kenya High Court (still undecided at the writing of this article and yet unreported) against the Kenyan government and the Kenyan Revenue Authority ${ }^{34}$ for signing a DTA with Mauritius that they allege is riddled with tax abuse loopholes, such as low withholding tax rates. ${ }^{35}$ The Tax Justice Network argues that the DTA contravenes the principle of good governance, sustainability, and accountability, in that it is in violation of Articles 10 and 201 of the Kenyan Constitution. The DTA was signed on 7 May 2012 and ratified by Kenya through a legal notice published in the Kenya Gazette on 23 May 2014 but it is not yet in force.

DTA low withholding tax rates have also been a concern for other African countries that have signed treaties with other low tax countries like the Netherlands, Switzerland and Luxembourg. In June 2013 Malawi terminated its 1969 colonial treaty with the United

\footnotetext{
$30 \quad$ Mauritius Offshore Business Activities Authority (MOBAA) 'Mauritius: A Sound Base for The New Millennium' (5 July 1999), http://www.mondaq.com/article.asp?articleid=7371\&searchresults=1 (accessed 28 November 2016). See also Schulze 1997: 185-6.

31 The East African, 'Rwanda-Mauritius tax treaty renegotiated', http://africamoney.info/rwanda-mauritius-tax-treatyrenegotiated-loopholes-closed/ (accessed 28 November 2016).

32 The DTA has retroactive application as from 1 January 2013 for Rwanda and as from 1 July 2013 for Mauritius. See The East African, 'Rwanda-Mauritius tax treaty renegotiated', note 31 above.

South African Government Gazette Number 18111. Date of Entry into Force 20 June 1997. The re-negotiated DTA between South Africa and Mauritius is set out in Government Gazette Number 38862 - Entry into Force 28 May 2015. J. Martin 'TJN Africa's challenge to "Ioophole-ridden" Kenya-Mauritius tax agreement to be heard in Kenya High Court', MNE Tax, 12 November 2015, http://mnetax.com/tjn-africas-court-challenge-to-loophole-ridden-kenya-mauritius-taxagreement-moves-forward-11832 (accessed 28 November 2016); and TJN Tax Justice Network-Africa 2015.

35 Note that the treaty sets the rate for interest at 10 per cent (the domestic tax rate is between 15-25 per cent) but Article 11 of treaties based on the OECD MTC also limit the interest rate to 10 per cent; for royalties the treaty rate is 10 per cent (the domestic rate is 20 per cent) however Article 12 of treaties based on the OECD MTC does not permit source countries to tax royalties; for dividends the treaty rate is 5 or 10 per cent depending on the shareholding (the domestic rate is 10 per cent). Article 10 of treaties based on the OECD MTC limits the rate to 5 or 25 per cent depending on the shareholding. See Axis, 'Kenya - Mauritius DTA ratified by the Republic of Kenya', http://www.axis.mu/uploads/DTA\%20Mauritius\%20\&\%20Kenya.pdf (accessed 28 November 2016).
} 
Kingdom, Northern Ireland and the Netherlands for this very reason. ${ }^{36}$ In 2014 Malawi resigned a treaty with the Netherlands (IMF 2014: 28) in the terms of which dividends will be subject to 5 per cent withholding tax in the case of shareholdings of at least 10 per cent, and the standard rates in both countries will apply to other dividends. Interest will be taxed at 10 per cent and royalties at 5 per cent. The low withholding tax rates in the Netherlands' DTAs with other African countries can still be prone to treaty shopping. For example, South Africa's treaty with the Netherlands can be subjected to treaty shopping by third country residents in order to circumvent South Africa's dividends withholding tax, which is imposed at a statutory rate of 15 per cent on dividend distributions by the subsidiary to its parent company. ${ }^{37}$ To circumvent this withholding tax rate, investments can be channelled through an intermediate holding company established in the Netherlands, to take advantage of the Netherlands/South African DTA, which limits the dividend withholding tax to 5 per cent provided the Dutch holding company holds at least directly or indirectly 25 per cent of the voting power in the company paying the dividends. ${ }^{38}$ The dividends could also qualify for the Dutch participation exemption $^{39}$ for foreign dividends. The Netherlands/South African DTA can also be used to reduce the South African withholding tax on royalties, ${ }^{40}$ levied at a rate of 15 per cent and reduced to zero in the treaty. Investors from a third country can license the supply of intellectual property (IP) to the Dutch holding company, which can sub-license the use of the IP to the South African subsidiary, thus avoiding the royalty withholding tax. The Dutch holding company may also not be subject to tax in the Netherlands, since it does not impose any withholding tax on royalties paid to a non-resident and merely requires a small margin for a Dutch holding company. ${ }^{41}$

Avoiding capital gains tax (CGT): Most African countries levy CGT. In a treaty context, Article 13(1) of treaties based on either the OECD or the UN MTC provides that income from the alienation of immovable property located in a country shall be taxable in that state. Article 13(2) gives the source country the right to tax capital gains derived from a PE located in that country. Article 13(3) is a special rule for gains from the alienation of ships or aircraft operated in international traffic which are taxable where the place of effective management of the enterprise is situated. In all other cases, (save for the anti-avoidance rule of Article 13(4) which is discussed ahead), Article 13(5) gives the right to tax proceeds from the alienation of any property to the resident state of the alienator. Article 13(5) presents BEPS concerns especially in treaties with low tax jurisdictions like Mauritius which does not impose CGT on its companies, with the result that companies investing through Mauritius completely avoid paying CGT and are able to earn large profits from their investments.

For example the Kenya/Mauritius DTA referred to above, which was ratified by Kenya on 23 May 2014, ${ }^{42}$ provides that capital gains arising from transfer of shares of a company shall be taxable only in the state in which the alienator is a resident. This implies that if the alienator is resident in Mauritius, then Mauritius would have the right to tax the gains derived from disposing of the shares. However since Mauritius does not levy CGT, those gains would not be subject to tax.

\footnotetext{
36 MNE Tax, Multinational tax and transfer pricing news, 'Netherlands renegotiates tax treaties with developing nations to add anti-abuse clause', http://mnetax.com/netherlands-renegotiates-tax-treaties-ethiopia-ghana-kenya-zambia-to-addantiabuse-clause-hopes-add-clause-23-treaties-9530 (accessed 28 November 2016).

Dividends withholding tax in South Africa is levied in terms of section of 64D to 64N of the Income Tax Act 58 of 1962 Article 10(2) of the Netherlands/South Africa DTA.

A participation exemption can be defined as a tax regime under which dividends received from foreign companies by resident companies are exempt from resident country tax if the resident company owns at least some percentage of the shares of the foreign company. See Arnold and Mclntyre 2002: 165 and Deloitte 'Taxation and Investment in Netherlands 2015': 10, https://www2.deloitte.com/content/dam/Deloitte/global/Documents/Tax/dttl-tax-netherlandsguide2015.pdf (accessed 29 November 2016).

Interest withholding tax in South Africa is levied in terms of section 37I to 37M of the Income Tax Act 58 of 1962

Deloitte 'Taxation and investment in Netherlands 2015', as note 39 above: para 4.3.

MNE Tax, Multinational tax and transfer pricing news, as note 36 above.
} 
In such situations, it is advisable for African countries to negotiate a provision in their DTAs to the effect that if the investor's resident country does not levy tax on a particular type of income then the source country would not give away its taxing right. As hinted above, Article $13(4)$ is an anti-avoidance measure, which provides that gains from the alienation of shares deriving more than 50 per cent of their value directly or indirectly from immovable property situated in a contracting state may be taxed in that state. However many African countries do not have this anti-avoidance rule in their DTAs. Thus MNEs often incorporate conduit companies in low tax jurisdictions, which are used to dispose of their shares in assets located in African countries so that the proceeds appear to be derived from such jurisdictions, thereby avoiding CGT in the relevant African countries. This is exemplified by the Ugandan court case of Zain International BV v Commissioner General of Uganda Revenue Authority. ${ }^{43}$ In this case, Zain International BV (hereinafter referred to as Zain) disposed of its shares in Zain Africa BV to Bharti Airtel International BV on 30 March 2010. All the three companies are incorporated and resident in the Netherlands. Zain Africa BV had equity interest in 26 Dutch BV Companies, among which was Celtel Uganda Holding BV that owned 99.99 per cent of Celtel Uganda Ltd. The Uganda Revenue Authority (URA) issued a tax assessment on Zain on the grounds that the transaction was one of gain arising from the disposal of an interest in immovable property located in Uganda, in terms of Article 13 of the DTA between Uganda and the Netherlands. Zain contended that the income was not sourced from Uganda as it had sold its shares in the Netherlands to a Netherlands entity, and so its income was sourced in the Netherlands and not in Uganda. The High Court, which did not consider the substantive tax treaty issues in the case, ruled that the URA had no jurisdiction to tax Zain International BV. The URA appealed this decision in the Court of Appeal, which ruled that Uganda had jurisdiction to tax proceeds on sale of shares between two foreign companies involving the sale of assets in Uganda. The Court of Appeal gave the URA an opportunity to study the transaction again and determine what taxes to claim.

However Zain has applied for Mutual Agreement Procedure in the Netherlands to resolve the case.$^{44}$ It is argued that if Uganda had secured the Article 13(4) anti-abuse provision in its treaty with the Netherlands, it would have been in a much more certain position in its claim against Zain (Hearson 2015: 24). This matter is one of the concerns that the Tax Justice Network raises in its above mentioned case against the Kenyan government with regard to the loopholes in the Kenyan/Mauritius treaty. Despite the anti-avoidance rule in Article 13(4) of the OECD MTC, which gives the right to tax shares to the source state, the Kenya/Mauritius DTA provides that capital gains on the disposal of shares by a Mauritius resident are only taxed in the residence state (Mauritius). In effect Kenya has given away the right to tax capital gains from stock sales of Kenyan companies to Mauritius, which does not levy CGT. ${ }^{45}$

(b) Abuse of tax sparing provisions in tax treaties: Treaty shopping is also encouraged by the tax sparing provisions that many African countries often insist on having in their DTAs with developed countries in an effort to encourage foreign investment (Easson 2004: 1-2; Hines 2001: 40; Holland and Vann 1989: 986). The argument is that when a developing country grants a tax incentive to an investor from a developed country treaty partner, the tax incentive may be eliminated or reduced where the investor's country applies the credit method to prevent the double taxation of income (Hines 2001: 40). To preserve the benefit of tax incentives granted to the foreign investor, a 'tax sparing' provision is included in the DTA, in terms of which the developed country amends its taxation of foreign source income to allow its residents who invest in developing countries to retain the tax incentives provided by

$43 \quad$ High Court of Uganda at Kampala (Civil Division) Miscellaneous Cause No. 96 of 2011

$44 \quad$ Mutual Agreement Procedure to resolve treaty disputes is set out in Article 25 of the Uganda/Netherlands DTA, which entered into force 10 September 2006. See D.K. Kalinaki 'Court gives URA nod to seek taxes on sale of Zain assets in Uganda' The East African, http://www.theeastafrican.co.ke/news/URA-taxes-on-sale-of-Zain-assets-in-Uganda//2558/2451578/-/item/0/-/6hm2he/-/index.html (accessed 29 November 2016).

45 J. Martin, 'TJN Africa's challenge to "loophole-ridden" Kenya-Mauritius tax agreement' to be heard in Kenya High Court' MNE Tax, 12 November 2015, http://mnetax.com/tjn-africas-court-challenge-to-loophole-ridden-kenya-mauritius-taxagreement-moves-forward-11832 (accessed 28 November 2016); and TJN 2015: 104. 
those countries (Rohatgi 20012: 213). The developed country is thus required to give a tax credit to the investor for the taxes that would have been paid to the developing country if the incentive had not been granted (Oguttu 2001: para. 2; Brooks 2008-9: 208). Tax sparing has, however, become rather unpopular and several developed countries have become restrictive in including tax sparing provisions in their tax treaties (Thuronyi 2003: 301). It is reasoned that tax sparing may not be that instrumental in promoting foreign investment and that it encourages abusive tax practices (Arnold and McIntyre 2002: 52-53) such as treaty shopping. Generous tax sparing credits in a particular treaty can encourage residents of third countries to establish conduit entities in the country granting the tax incentive (Arnold and McIntyre 2002: 52-53). Treaty shopping as a result of the tax sparing provision in the 1997 South Africa/Mauritius DTA was one of the reasons why it was renegotiated in $2015 .{ }^{46}$ The DTA no longer includes a tax sparing clause; rather, it allows for relief in the form of a foreign tax credit. ${ }^{47}$

Wrapping up on the factors that encourage treaty abuse in Africa, it should be noted though that in many African countries, the issue of curbing treaty shopping has not received much attention even though African tax officials often deal with multinational companies involved in treaty shopping. Most African countries' tax officials acknowledge that DTA negotiations have not fully taken into account the way DTAs could allow certain jurisdictions to act as conduits for tax avoidance (Hearson 2015: 6). However, over the last couple of years, there have been measures by some African countries to address issues of treaty abuse. In Ghana, effort is being made to strengthen the way DTAs are negotiated by doing more research into the potential treaty partner beforehand and bringing more diverse expertise into the negotiating team (ActionAid 2012: 22). In 2014, the Government of Uganda announced that it had suspended all of its ongoing DTA negotiations pending a review into the treaty terms that the nation should seek in such negotiations. ${ }^{48}$ Several African countries have renegotiated some of their DTAs that encouraged tax abuse. As stated above, in 2014 Malawi re-negotiated its DTA with the Netherlands; in 2015 South Africa re-negotiated its treaty with Mauritius (IMF 2014: 28); and Zambia is re-negotiating several of its old colonial-era treaties that were negotiated on poor terms (Hearson 2015: 1).

\subsection{Current measures to prevent treaty shopping}

To prevent treaty shopping, currently paragraph 7.1 of the Commentary on Article 1 of the OECD MTC (OECD: 2014d) provides that where taxpayers are tempted to abuse the tax laws of a State by exploiting the differences between various countries' laws, such attempts may be countered by jurisprudential rules that are part of the domestic law of the state concerned (for example general anti-abuse rules and judicial anti-abuse doctrines like the substance over form doctrine $)^{49}$ as well as the use of specific treaty anti-avoidance provisions (OECD Committee on Fiscal Affairs 1987 para. 4.2). For example, Ghana has a general anti-avoidance provision in section 34 of Income Tax Act 896 of 2015 to inter alia curb fictitious schemes whose form does not reflect their substance. South Africa also has general anti-avoidance provisions in section 80A-80L of Income Tax Act 58 of 1962 and it also applies the substance over form common law doctrine to prevent tax avoidance.

\footnotetext{
46 The re-negotiated DTA between South Africa and Mauritius is set out in Government Gazette Number 38862 - Entry into Force 28 May 2015.

47 See Article 22(2) of the DTA between South Africa and Mauritius. South African Government Gazette Number 38862 Entry into Force 28 May 2015

48 Ladu 'Govt suspends Double Taxation pacts', Daily Monitor, 6 June 2014, http://www.monitor.co.ug/Business/Govtsuspends-Double-Taxation-pacts/688322-2338432-dkw4jwz/index.html (accessed 29 November 2016); Hearson 2015: 1; and TreatyPro.com 'Latest Treaty Updates: Uganda', 10 June 2014,

http://www.treatypro.com/treaties_by_country/uganda.asp (accessed 29 November 2016).

49 Roper and Ware 2000: 77, where the 'substance over form' doctrine is described as a doctrine which permits the tax authorities to ignore the legal form of a tax arrangement and look at the actual substance of the relevant transaction.
} 
Although the commentaries on both the OECD and the UN MTC contend that there is no conflict between DTA provisions and domestic anti-avoidance rules since the latter merely establish the facts to which DTAs apply, ${ }^{50}$ DTA provisions are generally considered to prevail over domestic law since a DTA is a contract between the contracting states. To prevent arguments about treaty override, it is necessary that countries enact domestic anti-abuse rules that mirror the anti-abuse rules in their DTAs.

Currently the OECD and UN Commentaries on Article 1 also set out various examples of specific provisions that may be included in tax treaties to curtail treaty shopping. ${ }^{51}$ The main provision applied in most tax DTAs (even those signed by African countries) is the 'beneficial ownership' provision normally in Articles 10, 11 and 12 of both the OECD and UN MTCs, which deal with the taxation of interest, dividends and royalties respectively. ${ }^{52}$ Although the meaning of 'beneficial ownership' has internationally been unclear, ${ }^{53}$ the provision is intended to deny treaty benefits (in particular, reduced withholding tax on interest, dividends and royalties) to a conduit company, unless the beneficial owner is a resident of one of the contracting states. ${ }^{54}$ However the effectiveness of the beneficial ownership provision in curbing treaty shopping is now questionable in light of international court decisions such as the Canadian cases of Velcro Canada Inc. $v$ The Queen ${ }^{55}$ and Prevost Car Inc. $v$ The Queen, which ruled that the relevant taxpayers were beneficial owners and entitled to treaty benefits. ${ }^{56}$ The OECD acknowledges the limits of using the beneficial ownership provision as a tool to address various treaty-shopping situations. ${ }^{57}$ Thus in paragraph 12.5 of the 2014 version of the Commentary on Article 10, the OECD explains that: 'whilst the concept of 'beneficial ownership' deals with some forms of tax avoidance (i.e. those involving the interposition of a recipient who is obliged to pass on the dividend to someone else), it does not deal with other cases of treaty shopping and must not, therefore, be considered as restricting in any way the application of other approaches to addressing such cases'.

\subsection{OECD BEPS recommendations on preventing treaty abuse}

The OECD BEPS report on Action 6 notes that although current rules to prevent treaty abuse work well in many cases, they need to be adapted to prevent BEPS that results from interactions in more than two countries so as to fully account for global value chains (OECD 2013b: 19). In its 2015 Final Report on Action 6 (OECD 2015c) the OECD came up with minimum standards to prevent the granting of treaty benefits in inappropriate circumstances. In this regard, the OECD noted that a distinction has to be made between:

a) Cases where a person tries to circumvent the provisions of domestic tax law to gain treaty benefits. In these cases, treaty shopping must be addressed through domestic anti-abuse rules (as discussed above) (OECD 2015c: para. 15).

\footnotetext{
$50 \quad$ Para. 22 of the Commentary on Article 1 of the OECD MTC; Arnold 2004.

51 For example, the look through approach; subject to tax provisions; limitation of benefits provision; and the beneficial ownership provision. See Paras. 12-20 of the Commentary on Article 1 of the OECD MTC http://www.keepeek.com/Digital-Asset-Management/oecd/taxation/model-tax-convention-on-income-and-on-capitalcondensed-version-2014_mtc_cond-2014-en\#page1(accessed 29 November 2016). The provisions are explained in Oguttu 2007.

52 Article 10(2) of the OECD MTC

53 For example, para. 4.1 of the OECD MTC Commentary on Article 12 only indicates that a nominee or agent cannot be a beneficial owner; so is the case with a conduit company which has very narrow powers.

http://www.keepeek.com/Digital-Asset-Management/oecd/taxation/model-tax-convention-on-income-and-on-capitalcondensed-version-2014_mtc_cond-2014-en\#page1 (accessed 29 November 2016). See also International Fiscal Association 2000: 22.

Para 12.2 of the Commentary on Article 10 of the OECD MTC.

2012 TCC 57.

2008 TCC 231

OECD 'Clarification of the Meaning of "Beneficial Ownership" in the OECD Model Tax Convention: Discussion Draft' (29 April 2011 to 15 July 2011): 2, www.oecd.org/tax/treaties/47643872.pdf (accessed 8 December 2016).
} 
b) Cases where a person tries to circumvent limitations provided by the treaty itself. The OECD recommends that this should be addressed through treaty anti-abuse rules, using a three-pronged approach.

(i) The title and preamble of treaties should clearly state that the treaty is not intended to create opportunities for non-taxation or reduced taxation through treaty shopping (OECD 2015c: 9). Such a provision augments the treaty interpretation approach of preventing treaty abuse in Article 31 of the Vienna Convention on the Law of Treaties, which provides that treaties are to be interpreted in good faith and in the light of the object and purpose of the treaty. ${ }^{58}$

(ii) The inclusion of a specific limitation of benefits provision (LOB rule), which is normally included in treaties concluded by the United States and a few other countries. The OECD is of the view that such a specific rule will address a large number of treaty shopping situations based on the legal nature, ownership in, and general activities of, residents of a contracting state (OECD 2015c: para. 19).

(iii) To address other forms of treaty abuse, not covered by the LOB rule (such as certain conduit financing arrangements), tax treaties should include a more general anti-abuse rule based on the principal purpose test (PPT) rule. This rule is intended to provide a clear statement that the contracting states intend to deny the application of the provisions of their treaties when transactions or arrangements are entered into in order to obtain the benefits of these provisions in inappropriate circumstances (OECD 2015c: para. 19).

The OECD acknowledges that each rule has strengths and weaknesses and may not be appropriate for all countries (OECD 2015c: para. 20). It thus advises that the rules may be adapted to the specificities of individual States and the circumstances of the negotiation of DTAs. For example, some countries may have constitutional or certain legal restrictions that prevent them from adopting the recommendations. Some countries may have domestic antiabuse rules or interpretative tools developed by their courts that prevent some of the treaty abuses. In other cases, the administrative capacity of some countries (a major issue in African countries) may prevent them from applying certain detailed anti-abuse rules and require them to adopt more general anti-abuse provisions (for example the PPT rule) (OECD 2015c: para. 21). Nevertheless, the OECD recommends that at a minimum level, to protect against treaty abuse, countries should include in their tax treaties an express statement that their common intention is to eliminate double taxation without creating opportunities for nontaxation or reduced taxation through tax evasion or avoidance, including through treaty shopping arrangements (OECD 2015c: para. 22). This intention should be implemented through either:

- using the combined LOB and PPT approach described above; or

- the inclusion of the PPT rule or;

- the inclusion of the LOB rule supplemented by a mechanism (such as a restricted PPT rule applicable to conduit financing arrangements, or domestic anti-abuse rules or judicial doctrines that would achieve a similar result) that would deal with conduit arrangements not already dealt with in tax treaties (OECD 2015c: para. 22).

To ensure that African countries can effectively curtail treaty shopping, it is important that the right provisions, depending on their specific circumstances, are put in place. In principle, African countries should ensure that the preamble to all future DTAs they negotiate, or older DTAs they re-negotiate, should refer to the fact that the purpose of the treaty is not to create opportunities for non-taxation or reduced taxation through tax evasion or avoidance, including through treaty shopping arrangements. 
Regarding the feasibility of applying the LOB provision in preventing treaty shopping in Africa, it is important to understand the features of this provision (which was adopted from the USA). Essentially, the provision restricts entitlement to treaty benefits where a person is technically a treaty resident but lacks substantial connection with the residence jurisdiction. To be entitled to treaty benefits, such a resident has to pass the tests of a 'qualified person' (OECD 2015c: 21. In a nutshell, the terms of the provision as set out in the 2014 discussion draft on Action 6 provided that:

- A resident of a contracting state shall not be entitled to treaty benefits unless he/she constitutes a 'qualified person', which term is defined by reference to the nature or attributes of various categories of persons.

- A person is however entitled to the benefits of the treaty even if he/she does not constitute a 'qualified person' where (subject to certain exceptions) the relevant income is derived in connection with the active conduct of a trade or business in that person's State of residence. This 'derivative benefits' test allows certain entities owned by residents of other States to obtain treaty benefits that these residents would have obtained if they had invested directly.

- The LOB provision however provides for discretionary relief in that even if a taxpayer does not qualify for tax benefits, he/she may request to be treated as a qualified person if he/she is engaged in the active conduct of a business in its State of residence and the income is derived in connection with, or is incidental to, that business. In that case, the competent authority of a contracting state may grant treaty benefits where the other provisions of the LOB rule would otherwise deny these benefits (OECD 2015c: 21).

Essentially, this version of the LOB provision requires that treaty benefits (such as reduced withholding rates) are available only to companies that meet specific tests of having some genuine presence in the treaty country. However, such an LOB provision has not been applied in many DTAs other than those signed by the USA, and even then, the provisions vary from treaty to treaty. South Africa, for instance (one of the few African countries that has a DTA with the USA - others are Egypt, Morocco and Tunisia) $)^{59}$ has an LOB provision in Article 22 of its 1997 DTA with the USA. ${ }^{60}$ Although the LOB provision may be an effective anti-abuse provision, and although it offers some flexibility that allows for competent authority discretion, concerns have been raised that a complex LOB may hamper the ability of African countries with weak and limited administrative capacity to apply it, as it requires countries to have access to information so as to verify the pre-requisites of qualifying for treaty benefits (IMF 2014: 27). It should also be noted that in most cases, complex LOB provisions are intended to cover a number of sophisticated financing transactions that typically would not be an issue in developing African countries (UN 2015a: 33). In its 2015 Final Report, the OECD considered some simplified versions of LOB provisions (OECD 2015c: para. 25), which are now set out in Article 8 of the Multilateral Convention that the OECD finalised in 2016 in terms of Action 15 of the BEPS Report. The Multilateral Instrument is intended help countries implement tax treaty-related measures to prevent BEPS, without renegotiating each of their tax treaties (OECD 2016: Article 8). It is interesting to note that some African countries, such as Uganda, have a limited form of a LOB provision in their domestic tax laws. Section 88(5) of the Ugandan Income Tax Act (Cap. 340, as amended), provides that the benefits of any bilateral treaty are not available to a partner state-resident enterprise if 50 per cent or more of the underlying ownership of that enterprise of a partner state is controlled by individuals who are not resident in the partner state. Application of this domestic provision in a treaty, where there is no such provision in the treaty itself, may create disputes, as section 88(2) of Uganda's Income Tax Act clearly provides that an international agreement entered into by the government of Uganda with any foreign country prevails over the provisions of the Income Tax Act. The IMF advises that if developing countries adopt the LOB provision in

\footnotetext{
$59 \quad$ IRS 'United States income tax treaties A to Z' https://www.irs.gov/Businesses/International-Businesses/United-StatesIncome-Tax-Treaties---A-to-Z (accessed 29 November 2016). Published in Government Gazette No. 185553 of 15/12/1997.
} 
their domestic law, they should also adopt the provision in their DTAs to prevent treaty override concerns (IMF 2014: 28).

With regards to the use of a PPT test as a general measure to prevent treaty shopping, this could be a feasible approach for African countries, especially those that do not have general anti-avoidance provisions that could serve a similar purpose. In this regard, Ghana could be emulated, as it has a general anti-avoidance rule in section 34 of Income Tax Act 896 of 2015 that clearly defines tax avoidance to include any arrangement whose main purpose is to reduce or avoid tax liability. A similar main purpose provision exists in South Africa's general anti-avoidance provisions in section 80A-80L of Income Tax Act 58 of 1962 . The treaty PPT test, which has most of its influence from the United Kingdom, requires that treaty benefits are denied if one of the principle purposes of the transaction is to avoid taxation by taking advantage of treaty benefits (OECD 2015c: para 19). Over the last two years, the Netherlands appears to have changed its tax treaty policy with developing countries, which shows a proactive approach to using the PPT to prevent treaty abuse. The re-signed 2014 Netherlands/Malawi DTA contains an anti-treaty abuse provision (IMF 2014: 28) in Articles $10,11,12$ (which deal with interest, dividends and royalties respectively) to the effect that no relief shall be granted if the main purpose or one of the main purposes of any person is to take advantage of the treaty. The provision requires the competent authority of the contracting State which has to grant the benefits to consult with the competent authority of the other State before denying the benefits. The Netherlands has also renegotiated tax treaties with 23 other developing countries, including Ethiopia, Ghana, Kenya and Zambia. Each of these treaties has a PPT anti-abuse provision. ${ }^{61}$ The re-negotiated treaties also cover a provision on assistance in collection of taxes and also exchange of information in tax matters - which will be instrumental in uncovering BEPS practices. It is worth noting that for DTAs based on the UN MTC, paragraph 23 of the Commentary on Article 1 (UN: 2011) provides the following 'guiding principle' in dealing with situations relating to abuse or improper use of a treaty:

A guiding principle is that the benefits of a double taxation convention should not be available where a main purpose for entering into certain transactions or arrangements was to secure a more favourable tax position and obtaining that more favourable tax treatment in these circumstances would be contrary to the object and purpose of the relevant provisions.

It should however be noted that tests such as the PPT which rely upon notions of 'purpose' or 'intention' are normally difficult for tax administrations to administer and for taxpayers to comply with, as they require proof of intent. It would be advisable that in addition to such tests, African countries also rely on other more mechanical tests like the LOB provision to control the abuse of treaties (UN 2015a: 284).

Apart from the above provisions, the OECD also suggests specific anti-abuse provisions regarding certain types of income that countries must have in place. I will briefly pick on just two of them that are pertinent to African countries. The OECD recommends that countries should ensure their DTAs have Article 17(2) which is in both the OECD and the UN MTCs, and is aimed at personal services companies used by entertainers and athletes to avoid source-country tax. The OECD also recommends that countries should have Article 13(4) (discussed above) in their DTAs which allows countries to tax gains from the sale of shares of real estate holding companies to prevent the use of such companies to avoid taxation on gains on the underlying real estate. As discussed above, if Uganda had this provision in its DTA with Netherlands, it would have had a clear-cut claim in its case against Zain

$61 \quad$ MNE Tax, Multinational tax and transfer pricing news 'Netherlands renegotiates tax treaties with developing nations to add anti-abuse clause'. Available at http://mnetax.com/netherlands-renegotiates-tax-treaties-ethiopia-ghana-kenyazambia-to-add-antiabuse-clause-hopes-add-clause-23-treaties-9530 (accessed 29 November 2016). 
International. ${ }^{62}$ Currently paragraph 28.5 of the Commentary on Article 13(4) (OECD: 2014d) provides that States may want to consider extending the provision to cover not only gains from shares but also gains from the alienation of interests in other entities, such as partnerships or trusts, which would address one form of abuse. Under the BEPS project, the OECD has agreed that Article 13(4) will be amended to include such wording (OECD 2015c: para. 42). This development is most welcome for African countries that are concerned about investors circumventing CGT on the alienation of assets situated in in their jurisdictions. The OECD also noted that there might be cases where assets are contributed to an entity shortly before the sale of the shares or other interests in that entity, in order to dilute the proportion of the value of these shares or interests that is derived from immovable property situated in one contracting state. In order to address such cases, it was agreed that Article 13(4) should be amended to refer to situations where shares or similar interest derive their value primarily from immovable property at any time during a certain period, as opposed to at the time of the alienation only (OECD 2015c: para. 43).

Although the OECD has recommended provisions that countries could include in their DTAs to prevent treaty shopping, it is noteworthy that in general African countries are sceptical about extending their limited treaty network due to concerns about treaty abuse that are exacerbated by their general lack of treaty negotiating capacity. Indeed the IMF's 2014 report on spillovers recommends that developing countries should sign DTAs with considerable caution so as to guard against treaty shopping (IMF 2014: 22). It also recommends that due to the risks involved in signing tax treaties, 'countries should be well-advised before signing the treaties and that they should not enter treaties lightly', which is the case for many African countries that have signed DTAs mainly as political gestures (IMF 2014: 28). The IMF also notes that although one of the perceived advantages of a DTA is that it signals a strong commitment that gives tax assurance to foreign investors, such assurance can be achieved if a country builds up credibility in its tax policymaking capabilities (IMF 2014: 28). Before signing a DTA with any country, the IMF recommends that capital-importing countries (which is what most African countries are) should first consider whether they can achieve more by signing a treaty or by simply providing for key aspects (for example the permanent establishment definition - discussed below - and withholding tax rates) in their own domestic law to protect the tax base, as the envisaged benefits that a DTA could provide may actually be of relatively little value. Other important administrative aspects of DTAs, such as those relating to exchange of information in tax matters, could be achieved through signing Tax Information Exchange Agreements (TIEA) ${ }^{63}$ which provide a forum to exchange information even where a double tax treaty is not in place. For example, Kenya has initiated the process of signing TIEAs with Guernsey, Seychelles, Singapore and Bermuda, and is negotiating with Jersey, Cayman Islands, Isle of Man, and Malta (Taxwise 2014). South Africa has signed TIEAs with a number of countries including the Bahamas, Bermuda, Cayman Islands, Guernsey, Jersey and San Marino. ${ }^{64}$ The IMF also notes that treaty administrative aspects, such as assistance in the collection of taxes, can also be achieved by signing the OECD Multilateral Convention on Mutual Administrative Assistance in Tax Matters. ${ }^{65}$ African countries (which could be emulated) that have signed but not have not yet ratified this multilateral instrument are: Gabon, Kenya and Morocco. Those for which the treaty has now entered into force are: Cameroon (entered into force 1 October 2015), Ghana (entered into force 1 September 2013), Mauritius (entered into force 1 December 2015); Nigeria (entered

62 Zain International BV v Commissioner General of Uganda Revenue Authority. High Court of Uganda at Kampala (Civil Division) Miscellaneous Cause No. 96 of 2011.

63 In 2002 the OECD's Global Forum developed a Model Agreement on Exchange of Information on Tax Matters. See Oguttu 2014.

64 SARS 'International Tax Treaties - Tax Information Exchange Agreements', http://www.sars.gov.za/Legal/InternationalTreaties-Agreements/Pages/Exchange-of-Information-Agreements-(Bilateral).aspx (accessed 8 December 2016). IMF 2014: 28. The Multilateral Convention on Mutual Assistance in Tax Matters was developed by the Council of Europe and the OECD for member states in 1988. In 2010, the Convention was amended by a Protocol and opened to all countries. See OECD 'Convention on Mutual Administrative Assistance in Tax Matters',

http://www.oecd.org/tax/exchange-of-tax-information/conventiononmutualadministrativeassistanceintaxmatters.htm (accessed 29 November 2016) 
into force 1 September 2015), Senegal (entered into force 1 December 2016), Seychelles (entered into force 1 October 2015), South Africa (entered into force 1 March 2014), Tunisia (entered into force 1 February 2014) and Uganda (1 September 2016) ${ }^{66}$ ATAF also has a multilateral convention (which is not yet in force), which will be instrumental to African member countries since low tax jurisdictions like Mauritius are a part of it. It is thus important that African country tax administrations that are not part of ATAF endeavour to sign the ATAF Convention.

For African countries that are keen to expand their existing DTA network (UN 2015a: 275), but are not sure whether to enter into a DTA or terminate the abusive ones in place, the OECD, under its BEPS project, has identified tax policy considerations that, in general, countries should consider before deciding to enter into a DTA with a specific country (or to terminate one if changes to the domestic law of a treaty partner raise BEPS concerns) (OECD 2015c: para. 75). In this regard, the OECD has proposed to amend the Introduction to its MTC so that it includes these factors:

- Where a State levies no or low income taxes, other States should consider whether there are risks of double taxation that would justify a tax treaty.

- States should consider whether there are elements of another State's tax system that could increase the risk of non-taxation - these may include tax advantages that are ringfenced from the domestic economy.

- States should evaluate the extent to which the risk of double taxation actually exists in cross-border situations involving their residents; and they should note that many cases of residence/source juridical double taxation can be eliminated through domestic provisions for the relief of double taxation (ordinarily in the form of either the exemption or credit method) which can operate without the need for tax treaties.

- Since one of the objectives of tax treaties is the prevention of tax avoidance and evasion, States should consider whether their prospective treaty partner is willing and able to implement effectively the DTA administrative assistance provisions, such as the ability to exchange tax information and the willingness to provide assistance in the collection of taxes. In this regard, the OECD reiterates the IMF's recommendation (above) that these administrative assistance provisions could still be achieved through signing TIEAs ${ }^{67}$ or by signing the Multilateral Convention on Mutual Administrative Assistance in Tax Matters (OECD 2015c: para. 78).

- Where a State has concerns that certain features of the domestic law of the other State may raise BEPS concerns or that it might effect changes after the conclusion of a DTA, that may pose BEPS risks, the OECD has come up with proposals to be included in the MTC to restrict treaty benefits if taxpayers benefit from 'special tax regimes' with preferential tax rules, or where certain drastic changes are made to a country's domestic law after the conclusion of a treaty. These proposals will be finalised in 2016 (OECD 2015c: para. 81).

The OECD however recognises that there may be non-tax factors that can lead to the conclusion of a DTA, and that each country has a sovereign right to decide to enter into a DTA with any jurisdiction with which it decides to do so (OECD 2015c: para. 75 and OECD 2013b: 19).

\subsection{General recommendations to prevent abuse of tax treaties in Africa}

With respect to the OECD recommendations to curb treaty shopping, it can be concluded there is no 'one size fits all' in addressing treaty abuse issues. For African countries, the

\footnotetext{
66 OECD 'Jurisdictions Participating in the Convention on Mutual Administrative Assistance in Tax Matters. Status: 21 November 2016 ', http://www.oecd.org/tax/exchange-of-tax-information/Status_of_convention.pdf (accessed 29 November 2016).

67 In 2002 the OECD's Global Forum developed a model agreement on exchange of information on tax matters (Oguttu 2014).
} 
most appropriate method or combination of methods will depend on the basic legal structure of the country involved and the nature of the transaction. For African countries, the first line of defence against treaty abuse is to ensure that they have domestic general anti-avoidance rules in place. To ensure that the application of such domestic provisions is not considered as treaty override, effort should be made to ensure such general anti-avoidance provisions are aligned with the recommended treaty PPT rule so that the possibility of conflicts is removed.

Clearly Action 6 will result in changes to the OECD MTC which implies that, like other countries, African countries may have to renegotiate all their existing DTAs or to sign a protocol to include changes to the text proposed in the recommendations. Since the cost of such renegotiations in light of the number of treaties may not be feasible, African counties will have to consider joining the multilateral instrument proposed by the OECD in its BEPS Action 15 to implement measures developed in the course of the work on BEPS with respect to tax treaties.

To benefit from the OECD tax policy considerations that countries should consider before deciding to enter into a DTA or to terminate one, it is important that African countries take proactive measures to review their DTA policies. They could emulate Uganda, which in 2014 announced that it had suspended all of its ongoing double tax treaty negotiations pending a review into the treaty terms that it should seek in such negotiations. ${ }^{68} \mathrm{It}$ is important that such a review evaluate all a country's tax treaties to determine the ones that pose BEPS risks, especially those that lack anti-abuse provisions, those with zero or low withholding tax rates, and those with open-ended tax sparing provisions. Such DTAs should be negotiated to ensure an improved re-distribution of taxing rights. ${ }^{69}$ The decision to cancel a DTA should however not be taken lightly as it can impact on a country's international relations (IMF 2014: 22). To effectively prevent treaty abuse, a review of tax treaties alone is not enough. African countries should also review their domestic tax laws to ensure that they have the right to tax the relevant income. A treaty cannot impose tax where the income is not subject to tax under domestic legislation (IMF 2014: 22). In a situation where a DTA gives the right to tax a given type of income to a resident State, but that State's domestic law does not levy tax on that income, African countries should negotiate a provision in their DTAs that they would not give up their source taxing right.

\section{Action 7: Prevent the artificial avoidance of PE status}

The PE issue is perhaps one of the most concerning for developing countries such as those in Africa, whose source basis of taxation would be eroded if foreign investors avoided PE status (Glenn 2014). The PE concept is a crucial element of DTAs. Thus the exact content of the definition of a PE is of crucial importance to developing countries if they are to curtail its abuse (UN 2015a: 16). It is also important for them to know the differences in the definitions of the PE concept in the OECD and UN MTCs. Since the OECD MTC embodies rules and proposals by developed capital exporting countries (Arnold and Mclntyre 2002: 109), its definition of the PE concept is quite limited. The UN MTC, which favours capital importing countries over capital exporting countries, generally imposes fewer restrictions on the tax jurisdiction of source countries. Even though the UN MTC is historically based on the same principles and foundations as the OECD MTC, it offers a broader definition of the PE concept

\footnotetext{
$68 \quad$ Ladu 'Govt Suspends Double Taxation Pacts', Daily Monitor, 6 June 2014, http://www.monitor.co.ug/Business/Govtsuspends-Double-Taxation-pacts/688322-2338432-dkw4jwz/index.html (accessed 29 November 2016 
which is advantageous for source countries (Arnold and Mclntyre 2002: 109). The UN has over the years given special attention to developing countries and it has made efforts to protect and broaden the tax base of developing countries, as well to effectively combat tax evasion and tax avoidance in those countries (UN 2015a: viii).

In general, the PE concept is designed to limit source countries' tax jurisdiction over foreign businesses, and so it generally works in favour of residence countries (OECD 2013b: 19). The PE concept ensures that business activities are not taxed by a State unless a nonresident enterprise has created a taxable presence - which is a significant and substantial economic bond with that State (Vogel 1997: 280 para. 4). This paper does not cover a detailed analysis of the working of the PE concept; for that, the reader is referred to previous articles written by this author (Oguttu 2009b and Oguttu 2010). The emphasis of this paper is on the BEPS challenges posed to the PE concept. For a brief overview to set the background for the discussion ahead, suffice it to note that the PE concept is defined generally in Article $5(1)$ of the OECD and UN MTCs as 'a fixed place of business through which the business of an enterprise is wholly or partly carried on'. Article 5(2) provides an illustrative list of places that constitute PEs. ${ }^{70}$ Article 5(3) provides a special rule PE for building or construction or installation projects if they last for more than 12 months. Article 5(4)(a)-(f) lists a number of business activities (discussed below) which are treated as exceptions to the general definition of a PE in Article 5(1). The PE excluded activities are intended to limit the otherwise wide scope of the definition of a PE in Article 5(1). The policy reason being that a PE should only arise where a taxpayer has a sufficient connection with that State (Baker 2005: para. 5B.02). Apart from the physical places of business that constitute PEs, Article 5(5) provides for a deemed PE where a dependent agent habitually concludes contracts on behalf of the enterprise in the other contracting State. Some African countries have a definition of the PE concept in their domestic law that is aligned to the treaty meaning. For example, in South Africa, a PE is defined in section 1 of the Income Tax Act, ${ }^{71}$ with reference to the definition of the concept in Article 5 of the OECD Model Tax Convention.

The OECD notes that the PE concept has been under attack for years, both from multinationals that abuse it by compartmentalising it, and from developing countries that want to extend its parameters to reclaim their tax jurisdiction. ${ }^{72}$ The OECD acknowledges that the current definition of a PE is not sufficient to address BEPS strategies in the changing international tax environment, as its standards are ineffective in equitably allocating taxing rights between source and residence States (OECD 2014b: para 3). However the OECD emphasises that even though the BEPS Project will restore both source ${ }^{73}$ and residence ${ }^{74}$ taxation in a number of cases where cross-border income would otherwise go untaxed or would be taxed at very low rates, these action points are not directly aimed at changing the existing international standards on the allocation of taxing rights on cross-border income (OECD 2014b: para 3) or redrawing the boundaries between source and resident tax (OECD 2014b: para 3). Thus the OECD's approach to addressing the PE BEPS concerns is limited from the following perspectives:

The PE concept, which is largely based on having a physical presence in a State, is archaic in the face of twenty-first century electronic business models where transactions can be carried out without physical presence. However, the OECD does

\footnotetext{
$70 \quad$ Examples are: a place of management; a branch; an office; a factory; a workshop; a mine, an oil or gas well, a quarry or any place of extraction of natural resources. This list is not exhaustive. Para. 4 of the Commentary on Article 5(2) of the OECD MTC; Baker 2005: para. 5B.02.

Act 58 of 1962

Ibid.

Under source taxation, persons are taxed on income that originates within the territorial jurisdiction or geographical confines of the country, despite the taxpayer's country of residence. See Meyerowitz 2008: para 7.1.

Under residence taxation, residents are taxed on their worldwide income regardless of the source of the income. See Meyerowitz 2008 para 7.1
} 
not consider an overhaul of the PE concept. Its project is limited to addressing 'artificial avoidance of PE status'.

In terms of Article 7(2) of the OECD MTC, only profits attributable to a PE are taxable in the source state. The attributable profits are those which a PE would have earned if instead of dealing with its head office, it had dealings with an entirely separate enterprise under conditions and at prices prevailing in the ordinary market. In effect, the PE is treated as if it were a separate legal entity (Arnold and Mclntyre 2002: 74). The OECD still upholds this separate entity principle even though modern MNEs often operate as a single unified enterprise, managed from a central location by managers who are responsible for the enterprise as a whole (Avi-Yonah and Clausing 2008). Interestingly even the OECD acknowledges that international tax principles (such as this one on attributing profits to PEs) that fail to keep pace with the changing business environment and are still grounded in an economic environment characterised by a lower degree of economic integration across borders will not be effective in curtailing BEPS (OECD 2013b: 47).

In Action 7, the OECD reinforces international tax standards that will result in changes to Article 5 of the MTC and thus prevent artificial avoidance of PE status. The discussion below is divided into three sections:

- Issues pertaining to preventing avoidance of PE status that are addressed in the OECD BEPS project;

- $\quad$ Issues pertaining to preventing avoidance of PE status that may be of concern to developing countries but are not addressed by the OECD BEPS project;

- $\quad$ Issues pertaining to preventing avoidance of PE status to be addressed post-2015.

\subsection{Issues pertaining to preventing avoidance of PE status that are addressed in the OECD BEPS project}

\subsubsection{Prevent avoidance of PE status through commissionaire arrangements}

Article 5(5) of both the OECD and the UN MTCs provides for a deemed PE if a dependent agent has authority to conclude contracts in the name of the enterprise supplying the goods. However this provision can be circumvented if it is interpreted to mean that the agent must have the legal authority to bind the supplier at the end of the contract negotiations in order for a PE to exist, regardless of the extent of the agent's activities in the source country. In countries with a civil law code, commissionaire agent arrangements can be structured to ensure that the contacts concluded by the agent are not concluded in the name of the supplier (the principle), in that they bind only the agent even though the principle will supply the goods on the terms agreed to by the agent. This implies that the supplier would technically not have a PE in the source country and so only the 'low risk' sales commission (not the real profit on the sale of the goods) would be taxed in the country of sale. ${ }^{75}$

To prevent BEPS that arises as a result of commissionaire arrangements, the OECD recommends that as a matter of policy, where the activities that an intermediary exercises in a country are intended to result in the regular conclusion of contracts to be performed by a foreign enterprise, that enterprise should be considered to have a taxable presence in that country unless the intermediary is performing these activities in the course of an independent business (OECD 2015c: 10). This matter is of most concern to civil law jurisdictions that have provisions relating to commissionaire arrangements. Since most African countries apply common law, issues pertaining to commissionaire arrangements are not discussed any further in this paper. It is however worth noting that there may be cases where proxies are employed to escape the dependent agency PE rules in Article 5(5) that African countries

See Zimmer Ltd French Supreme Court, No. 3047 15, 31 Mar 2010; Dell AS Norwegian Supreme Court, HR-201102245A, 2 Dec 2011; and Boston Scientific International BV Italian Supreme Court, No. 3769, 9 Mar 2012. 
should be wary of, as these could pose BEPS risks. For example, in the South African case of SIR v Downing, ${ }^{76}$ Downing immigrated to Switzerland in 1960 and ceased to be a South African resident. Due to South Africa's exchange control regulations, he could not move part of his share portfolio from South Africa. Downing authorised a stockbroker to ensure his share portfolio yielded income. The revenue authorities included the proceeds in Downing's gross income. It was however held that by virtue of Article 5(5) of the South

Africa/Switzerland DTA, the income was not taxable in South Africa as the stockbroker was an independent agent, acting in the ordinary course of his business.

\subsubsection{Splitting-up of contracts by contractors to circumvent PE time limits}

Article 5(3) of the OECD MTC provides for a special PE rule for building sites, construction and installation projects that last for more than 12 months. However, contractors and subcontractors, particularly those engaged in exploration and exploitation on the continental shelf, often abuse the 12 month PE time limit by dividing contracts into several parts, each covering a period of less than 12 months, and yet all owned by the same group. ${ }^{77}$ Manipulating PE time limits is a major concern for Africa countries, especially so for construction, assembly and similar activities where, as a result of modern technology, a very short time period could be spent in the source country and still result in a substantial profit for the foreign enterprise. ${ }^{78}$ To address these concerns, paragraph 18 of the Commentary on Article 5 of the OECD MTC currently recommends that such abuses may be prevented by the application of domestic legislative or judicial anti-avoidance rules; and that countries can also devise solutions in the framework of bilateral negotiations.

In practice however, many developing countries tend to apply a wider view of taxable presence for contractors and sub-contractors by negotiating an Article 5 that is based on the UN MTC. Article 5(3)(a) of the UN MTC deviates from the OECD MTC in that it covers not only building sites, construction, installation projects (covered in Article 5(3) of the OECD MTC), but also 'assembly projects or supervisory activities in connection therewith'. The manipulation of time limits to avoid PE status is also limited in the UN MTC, in that the above mentioned projects or activities constitute a PE if they last more than six months (unlike the 12 month time limit in the OECD MTC). Some African countries have managed to negotiate an Article 5(3)(a) based on the UN Model, for example Article 5(3) of Uganda's treaties with Mauritius, South Africa, Netherlands and the UK follow the UN Model. Since African countries are predominately capital-importing countries, it would be in their interest to sign DTAs with Article 5(3)(a) of the UN MTC which has a six month rule as well as the express inclusion of assembly projects and supervisory activities (Akunobera 2012: 1078). However, it would be much better if they could negotiate lesser days considering that some construction activities, for instance by Chinese companies, can be completed in three months (Hearson 2015: 21).

\subsubsection{Splitting of service contracts to avoid PE status}

This is a concern with regard to MNEs engaged in service activities, such as the services of consultants, who often allege that the activities of these consultants or engineers are of a temporary nature. To address these concerns, currently paragraph 42.45 of the OECD Commentary on Article 5(4) recommends that legislative or judicial anti-avoidance rules may be applied to prevent such abuses. Paragraph 42.23 of the OECD Commentary on Article 5 also suggests an alternative service-PE provision that countries may include in their treaties. Issues of splitting service contracts are pertinent for African countries, as PE status can be avoided by MNEs if an enterprise fragments its activities among related enterprises, or if it uses related non-resident enterprises to carry out connected projects (UN 2015a: 40). If this

Para. 18 of the Commentary on Article 5(3) of the OECD MTC.

Para. 10 of the Commentary on Article 5(3) of the UN MTC (2014 version). 
matter is left to contracting states to negotiate a service-PE, many African countries with weak treaty negotiating capabilities may not be successful in negotiating such a provision. Thus many developing countries tend to negotiate Article 5(3)(b) of the UN MTC, which categorically sets out a special PE service provision that covers the furnishing of services, including consultancy services, by an enterprise of a contracting State in the other State, through employees or other personnel engaged by the enterprise if those activities continue (for the same or a connected project) for an aggregate period of more than 183 days in any 12 month period. ${ }^{79}$ The use of the phrase 'same or a connected project' in Article 5(3)(b) implies that when contracts are split to avoid PE thresholds, only commercial coherence, not geographical coherence, is required, unlike Article 5(1) which requires both (UN 2015a: 375). It should also be noted that only working days during which services are performed by the employees of the enterprise in the source country are taken into account. Days during which employees or other personnel are merely present in the source country but are not working are not counted. Developing countries, such as those in Africa, tend to include this UN MTC provision in Article 5 of their treaties because they believe that the provision of management and consultancy services in their countries by enterprises of industrialised countries can generate large profits if those activities continue for an extended period. ${ }^{80}$ However since the effectiveness of Article 5(3)(b) depends on whether the tax authorities can detect the presence of the service provider for more than 183 days in their country (which is a question of fact), it can still be possible to avoid the conditions of the article. The 183-day time limit can for instance be manipulated through artificial splitting of the connected projects to meet the time threshold (UN 2015a: 375) and preclude taxation in the case of a continuous number of separate projects. This is especially so with modern technology, where even a short duration can result in substantial profits for the enterprise. ${ }^{81}$ To address this matter, some African countries have negotiated time limits that are lower than the 183-day threshold. For example, Article 5(3)(b) in Uganda's DTAs with Mauritius and Netherlands provides for a four month time limit for furnishing services.

Even though Article 5(3)(b) of the UN MTC can be instrumental in preventing splitting of service contracts in that services for the same or a connected service provider are aggregated when counting the number of days that the services are performed in the source country, there can still be abuses since the provision does not take into account services provided by related enterprises with respect to the same or connected projects. A MNE carrying on business in a developing country may use its subsidiary company resident in a low-tax country to provide services (such as legal, accounting, management and technical services) to the company in the developing country, which may not require employees of the non-resident service provider to be present in the developing country for long periods of time. To prevent such abuses, effective exchange of information on such related enterprises would be required by tax administrations of the relevant countries (UN 2015a: 40).

Nevertheless, a South African tax court ruled on the presence of a service PE in the 2015 case of AB LLC and BD Holdings Tax $v$ the Commissioner of the South African Revenue Services, ${ }^{82}$ in which the courts dealt with an Article 5 provision in the South African/USA DTA which is similar to the one in the UN MTC. The company in issue provided strategic and financial services in South Africa whereby its employees occupied the boardroom at the recipient's premises to conduct those services. The company's employees spent a period exceeding 183 days in South Africa. The Commissioner assessed the company for income earned from the services rendered on the basis that the company operated from a PE as contemplated in Article 5(2)(k) of the DTA, which included in the meaning of a PE the furnishing of services, including consultancy services, by an enterprise through employees if the activities continue (for the same or a connected project) for an aggregate period of more

\footnotetext{
Para. 9 of the Commentary on Article 5(3) of the UN MTC; Arnold and McIntyre 2002: 121.

Para. 9 of the Commentary on Article 5(3) of the UN MTC.

Para. 10 of the Commentary on Article 5(3) of the UN MTC.

Tax Court Case number 13276 May 2015.
} 
than 183 days in any 12 month period. The court ruled that since the company provided consulting services through its employees in South Africa for a period exceeding 183 days, a PE had been created. Even Article 5(1) of the DTA could be applied in that the boardroom where the services were performed constituted a fixed place of business. So the income earned by the company was attributable to that PE and taxable in South Africa.

OECD BEPS Project recommendation on splitting of contracts: To prevent PE abuse when contracts are split up between closely related enterprises, the 2015 BEPS Final Report on Action 7 recommends that the principal purposes test (PPT) rule that will be added to the OECD Model MTC as a result of the adoption of the OECD Report on 'Action 6: Prevent treaty abuse' (discussed above) should address the BEPS concerns related to such abuses (OECD 2015e: 10).

Despite this recommendation, developing countries are concerned that the OECD's approach of addressing BEPS issues arising from manipulating service activities is not effective. As explained above, in a treaty context, where a non-resident service provider renders services in the other contracting state, that state may only tax the foreign service provider if it qualifies as a PE in terms of Article 5. Under the UN MTC, the consultant may also be treated as having earned income from providing 'independent personal services' (in terms of Article 14), if they have a 'fixed base' 83 that they regularly use in the source state. However, Article 14 was deleted from the OECD MTC in 2000 and its coverage was introduced in Articles 5 and 7 of the OECD MTC with the reasoning that there were no intended differences between the PE concept and fixed base concept as in both cases, profits would be attributed in terms of Article 7 (Arnold and Mclntyre 2002: 122). Either way, proving that a service PE or a fixed base has been created is very complicated as service providers often come up with artificial schemes to avoid being caught by the rules. Since only profits attributable to a PE are taxed in the source state, Article 7 requires that the arm's length principle is applied in attributing those profits. However, enforcing the arm's length principle with respect to service fees is cumbersome for source countries because it is difficult to verify whether the service fee payments are appropriate.

In its 2015 Report on BEPS (OECD 2015e: para 20), OECD acknowledges that BEPS concerns regarding the PE concept in the context of service fees cannot be addressed successfully without coordinating the work on PEs with work on other actions, in particular Action 10, which deals with transfer pricing of high risk transactions (Arnold and Mclntyre 2002: 53). In Action 10, the OECD proposed revisions to Chapter VII of the Transfer Pricing Guidelines to guide taxpayers on how to benchmark transactions involving cross-border services so as to protect against common base eroding payments. The guidance entails a simplified elective method for determining arm's length charges for common low valueadding intragroup services which require a very limited profit mark-up on costs (OECD 2015d: 141). The approach removes the detailed arm's length benchmarking of the benefits received and creates a low cost methodology for pricing low value-added services. The OECD defines low value-adding intragroup services as those that are: supportive in nature; not part of the core business of the MNE group; do not require the use or creation of unique and valuable intangibles; and do not involve the assumption or control of significant risk (OECD 2015d: 153). Examples of such services are: accounting and auditing; processing and management of accounts; human resources activities; monitoring and compilation of data; information technology services; public relations support; legal and tax obligation services; as well as services of an administrative or clerical nature (OECD 2015d: 154). Excluded services are: services constituting the core business of the MNE group; research and development; manufacturing and production; purchasing raw materials used in

83 The term 'fixed base' is not defined in the UN MTC, neither was it defined in the OECD MTC before it was deleted. Para. 10(4) of the Commentary on Article 14 of the UN MTC notes that 'it has not been thought appropriate to try to define [the term 'fixed base'], but it would cover, for instance a physician's consulting room or the office of an architect or a lawyer'. 
manufacturing or production; sales, marketing and distribution activities; financial transactions; extraction, exploration, or processing of natural resources; insurance and reinsurance; and services of corporate senior management (OECD 2015d: 153-4).

The OECD suggests that where excessive charges for intragroup management services are viewed as being a major BEPS challenge, a threshold can be put in place whereby, for services that exceed the threshold, a full transfer pricing analysis is performed (OECD 2015d: 159). The OECD notes that for this approach to work, many countries need to agree on adopting it before 2018. In principle OECD members have agreed to the approach and associated countries (which include South Africa) are considering it (OECD 2015d: 142). The OECD would then design the structure of the threshold and other implementation issues. It would be in the interest of a developing country that lacks a data base for comparability to support efforts to develop this approach as it would reduce the costs for taxpayers and administrative burdens for SARS.

It is important that developing countries take into consideration the above OECD Guidance as well as the work of the G20 Development Working Group, which was mandated to develop toolkits that will help developing countries implement measures to protect their tax base from excessive intragroup service charges (OECD 2015d: 142).

It should be noted though that there has been widespread dissatisfaction by source countries regarding their entitlement to tax services, even if a PE or a fixed base could be proved to exist, because of the erosion of source country tax bases (UN 2015a: 95). Where there is no tax treaty in place, a practical method applied by many African countries to prevent base erosion is to levy a withholding tax on service fees on a gross basis without a deduction for expenses incurred. South Africa for instance has a withholding tax on service fees, as does Uganda and Ghana. ${ }^{84}$ To further protect their tax bases, some developing countries have opted to sign treaties with articles on services fees (often combined with management fees and technical fees) which currently deviate from the OECD and the UN MTCs. Generally there is no clear definition of such services, but the treaties that have these articles broadly define services, management and technical fees as "payments of any kind to any person, other than an employee of the person making the payments, in consideration for any services of a managerial, technical or consultancy nature, rendered in a contracting state'. ${ }^{85}$ In terms of these articles, the service fees are taxed in the resident state but they may also be taxed in the source state if the beneficial owner thereof is a resident of the other contracting state. In that case, the charge for the fee shall not exceed a certain percentage of the gross amount as agreed upon. For example, Ghana has signed treaties with Germany and Netherlands with combined 'royalties and service' fees. ${ }^{86}$ Uganda has signed treaties with South Africa and the United Kingdom which contain an article on 'technical fees' ${ }^{87}$ Provisions on services, managements and technical fees do not only appear in treaties signed by African countries: Article 12 of the US-India tax treaty deals with royalties and

84 South Africa levies at a flat rate of 15 per cent as per Part IVC in Chapter II of Income Tax Act 58 of 1962 - to come into operation on 1 January 2017; Uganda levies the equivalent termed 'management fees' at a rate of 15 per cent in terms of section 83(1) of Uganda's Income Tax Act, Chapter 340; Ghana levies management and technical services fees/endorsement fees at a rate of 15 per cent in terms of the Ghana Income Tax Act 896 of 2015.

85 For example, Article 12(4) of the Double Taxation Agreement between Ghana and Germany, entered into force 14 December 2007. www.nyansa-africa.com/wp-content/uploads/2015/08/Ghana-Germany-DTA.pdf (accessed 30 November 2016)

86 See Article 12 of the Ghana and Germany treaty. See also Article 12 of the Double Taxation Convention between The Netherlands and Ghana, entered into force 10 March 2008.

http://download.belastingdienst.nl/itd/verdragen/overige/belastingverdrag ghana.pdf (accessed 30 November 2016). Article 13 'Technical fees' of the Double Taxation Agreement between South Africa and Uganda, entered into force 9 April 2001.

www.ura.go.ug/openFile.do?path=//webupload//upload//download//staticContent//RGTMENU//458//464_IBFD_-

SOUTH_AFRICA_-_UGANDA_INCOME_TAX_TREATY.pdf (accessed 30 November 2016). See also Article 13 of the Double Taxation Convention between the United Kingdom and Uganda, entered into force 21 December 1993. www.gov.uk/government/publications/uganda-tax-treaties (accessed 30 November 2016). 
service fees. ${ }^{88}$ Research conducted in 2012 found that ' 134 of the 1,586 tax treaties concluded internationally between 1997 and 2011' contained an article on fees for technical services (Wijnen, de Goede and Alessi 2012). However there is no standard way of drafting these articles, which makes treaty negotiations very difficult and creates uncertainties for taxpayers. Since the articles on these types of fees deviate from what is in the MTCs, the provisions adopted tend to be less well thought through than those arising from debate and negotiation under the OECD or the UN MTCs. Despite the widespread use of the articles on fees, the OECD does not advocate for such an article in its MTC and so this matter has not been addressed in the BEPS Project. Rather, the OECD prefers to tax services under Article 5 , thus giving the residence countries of MNEs that specialise in high value services a bigger share of the right to tax those profits. In 2013 the UN decided to add a new article on income from technical services in its MTC which would allow developing countries to levy a tax on payments made to overseas providers of 'technical services'. The UN's proposed article on technical services will be included in the 2017 update of its MTC. Developing countries are looking forward to this service fee article as it will give validity to their position on this matter, and help them to successfully negotiate such a provision in their treaties. If they can manage to do so, developed countries may insist on high concessions (like low withholding taxes) if they give in to a technical service fee article. It should however be noted that African countries must still must enact domestic law that allows them to tax income from technical services derived by non-resident service providers, since a treaty cannot levy tax if the income is taxed under domestic law.

\subsubsection{Artificial avoidance of PE excluded activities}

(a) The word 'delivery' in Article 5(4)(a) and (b): The meaning of a PE in the OECD MTC does not include:

a) the use of facilities solely for the purpose of storage, display or delivery of goods or merchandise belonging to the enterprise;

b) the maintenance of a stock of goods or merchandise belonging to the enterprise solely for the purpose of storage, display or delivery.

In its 2014 Discussion Draft on Action 7 (OECD 2014b), the OECD acknowledges that it is difficult to justify the application of exception (a) and (b) to the PE concept where an enterprise maintains a very large warehouse in which a significant number of employees work for the main purpose of delivering goods that the enterprise sells online (OECD 2014b: paras. 18-19). The OECD is however of the view that even if the delivery of goods is treated as giving rise to a PE, only a small amount of income could properly be attributed to this activity and that if the issue is not given close consideration, tax authorities might end up attributing too much income to this activity, which would lead to prolonged litigation and inconsistent application of tax treaties (OECD 2014b: paras. 18-19). Thus no further consideration of this matter is dealt with in the OECD Final Report on Action 7. However, avoiding PE status as a result of including the word 'delivery' in the exclusions to the PE concept is of concern to developing countries which argue that a stock of goods for prompt delivery facilitates the sale of products and earning profits in the host country. The UN MTC address this matter by ensuring that the word 'delivery' is not referred to in subparagraphs (a) and (b). This implies that a warehouse used for delivery purposes should be a PE, if the requirements of Article 5(1) are met, thus permitting source countries to tax income derived from the operation of a warehouse (Arnold and Mclntyre 2002: 121). Concerns related to use of the word 'delivery' in the OECD MTC are connected to instances where a MNE has a dependent agent in a state, who maintains a stock of goods in a warehouse from which products are delivered to customers in that state, thereby carrying out significant business in the host country. In terms of the OECD MTC, such activities of the dependent agent would

88 'The Convention between the Government of the United States of America and the Government of the Republic of India for the Avoidance of Double Taxation and the Prevention of Fiscal Evasion with Respect to Taxes on Income', Effective date 1 January 1991. www.irs.gov/pub/irs-trty/india.pdf (accessed 30 November 2016). 
not constitute a PE since Article 5(5) provides that a dependent agent is only deemed to exist if such agent habitually concludes contracts on behalf of the enterprise in the other contracting state. However, the UN MTC covers the above concern in that it has an additional Article 5(5)(b) which includes in the meaning of a dependent agent 'the maintenance of a stock of goods or merchandise belonging to the enterprise from which he regularly delivers goods or merchandise on behalf of the enterprise' (UN 2011: Article $5(5)(b)$. Uganda's treaty with Mauritius follows this UN approach. It would be in the interest of African countries to ensure they have this provision in the DTAs they negotiate.

(b) Maintenance of a stock of goods for the purpose of processing: Article 5(4)(c) excludes from the PE concept the 'maintenance of a stock of goods or merchandise belonging to the enterprise solely for the purpose of processing by another enterprise'. An important BEPS issue is whether an enterprise's stock of goods maintained by a tollmanufacturer will result in the location of the toll-manufacturer's activities being a PE of the enterprise. Basically, a toll-manufacturer is a company that processes raw materials or partly completed goods for another company in exchange for a toll. ${ }^{89}$ In terms of the current PE rules, if a toll manufacturer maintains a stock of goods for processing and stores them for delivery to the enterprise, a PE would not be constituted. However in modern business models a toll manufacturer could be part of the MNE group of companies, and so it is necessary to determine if the maintenance of goods for the purpose of processing creates a PE for the MNE.

(c) Purchasing goods or merchandise or collecting information for the enterprise: Article $5(4)$ (d) excludes from the PE concept 'the maintenance of a fixed place of business solely for the purpose of purchasing goods or merchandise or of collecting information, for the enterprise'. However modern business models, especially digital MNEs, can collect information for the enterprise and disguise it by repackaging it into reports prepared for those enterprises, thereby avoiding PE status (OECD 2014b: para. 28). It is necessary that where a MNE has a connected affiliate in a source state that collects information that is related to the business as a whole, such an affiliate should be considered a PE of the MNE.

(d) Preparatory or auxiliary activities: Articles 5(e) and 5(f) prevent an enterprise from being taxed in the other state, if it only carries on activities of a purely preparatory or auxiliary character..$^{90}$ There has, however, been uncertainty about the meaning of the phrase 'preparatory or auxiliary'. The Botswana case of Transvaal Associated Hides and Skin Merchants $v$ Collector of Taxes, Botswana, ${ }^{91}$ illustrates this concept. The taxpayer in issue was a company, incorporated in South Africa, which was in the business of buying and selling hides and skins of slaughtered livestock. The hides were purchased from abattoirs in Botswana but the sales and taking of orders was processed in South Africa. From 1954 to 1961, the taxpayer processed hides from an abattoir in Lobatsi, Botswana. Before the hides could be delivered to the respective purchasers they had to be cured to prevent damage. The process of curing the hides required stacking them in piles and leaving them to stand for a period of between 11 to 21 days; they were then sorted into grades and despatched to purchasers. For this purpose the taxpayer maintained a shed in Lobatsi. The Collector of Income Tax, Botswana, sought to tax the taxpayer on the profits earned from the sale of the hides purchased and cured at Lobatsi, arguing that the taxpayer had created a PE in Botswana. The taxpayer argued that the activities of curing the hides that were carried out in Botswana were excluded from the PE concept since they were merely preparatory or auxiliary in nature, and that the shed in which the hides were stacked amounted to a warehouse or depot for further delivery. Dismissing the taxpayer's contention, Judge J. A. Maisels stated, regarding the curing process: 'It is to my mind clear that the activities of the

\footnotetext{
89 Hiring a toll manufacturer often ensures efficiency, and it also lessens pre-production costs as no capital investments are required.

Para. 18 of the Commentary on Art 5(4); see also Holmes 2007: 156.

Transvaal Associated Hides and Skin Merchants v Collector of Taxes, Botswana 29 SATC 97: 115.
} 
appellant went beyond the mere purchase of goods or the storing of goods in a warehouse for the convenience of delivery.' Furthermore, that since the taxpayer held the shed from 1954 to 1961, it constituted premises and a PE that the taxpayer had at its disposal in Botswana which was not 'temporary or occasional, but was permanent'.

An example of preparatory or auxiliary activities given in Article 5(4)(e) is the maintenance of a fixed place of business solely for the purpose of advertising or the supply of information or for scientific research. However, in the modern world, real value can be created through scientific research as well as the development and testing of products in continuous processes of innovation and improvement. Spending on innovation is key to the success of many businesses today. However, under the current rules, a MNE could claim its research and development activities that are relevant for the sale of final products are preparatory or auxiliary in nature. Since the OECD's BEPS project is about ensuring that profits are taxed where economic activities generating the profits are performed and where value is created (OECD 2013a: 10), it is important to acknowledge that the true value of the MNEs profits cannot be determined without considering the value contributed through research and development, or the creation of products in source countries. Otherwise, the concept of 'preparatory or auxiliary' activities only serves as a loophole for fragmenting activities without attaining the threshold of a PE in source country.

\section{OECD recommendation on preparatory or auxiliary activities: The OECD BEPS Report} acknowledges that depending on the circumstances, business activities that were previously considered to be merely preparatory or auxiliary in nature may nowadays be an enterprise's core business activities. In order to ensure that profits derived from core activities performed in a country can be taxed in that country, the OECD will modify Article 5(4) in its next update to the MTC to ensure that each of the exceptions to the PE concept, not only paragraphs (e) and (f), are restricted to activities that are of a preparatory or auxiliary character (OECD 2015e: 10).

Previously, the meaning of the terms 'preparatory or auxiliary' was not clear, causing disagreements regarding how to identify an enterprise's core business. In light of Action 7 , the OECD Commentary on Article 5(4) will clarify what is considered to be a preparatory or auxiliary activity. A preparatory activity would be one which precedes the main activity, one that is carried out for a short period of time, or an activity that is determined by the character of the main activity of the enterprise (OECD 2015e: 17). For example, training employees prior to commencing construction would be seen as a preparatory activity. An auxiliary activity would be considered to be a 'supportive' activity and not necessarily considered to be vital to the main activity being carried out. Thus, where an activity requires a significant amount of assets or employees to be conducted, such an activity cannot be considered to be auxiliary in nature.

(e) Fragmentation of activities between related parties: MNEs can avoid PE status by fragmenting activities and taking advantage of Article 5(4)(f), which excludes from the PE concept 'the maintenance of a fixed place of business solely for any combination of activities mentioned in subparagraphs (a)-(e), provided that the overall activity of the fixed place of business resulting from this combination is of a preparatory or auxiliary character'. However, the wide application of Article 5(4)(f), which covers a combination of activities, often creates nexus in the source country that is not preparatory or auxiliary. It also encourages the fragmentation of operations, typically in contracting and customer delivery activities, as well as in production activities, to ensure that disproportionate profits are attributed to affiliates in countries with lower effective tax rates. Fragmentation of activities also often occurs where manufacturing is outsourced so that production appears to be carried out in low tax jurisdictions (although there may not be much substance in such activities), but the outsourcing is merely done to ensure profits are subject to lower taxes. Currently, paragraph 27.1 of the OECD Commentary on Article 5(4)(f) does acknowledge that an enterprise 
cannot fragment a cohesive operating business into several small operations in order to argue that each is merely engaged in a preparatory or auxiliary activity.

OECD recommendation on fragmentation of activities: In its 2015 final report on Action 6 (OECD 2015b), the OECD reiterates this view. Given the ease with which MNEs may alter their business structures to obtain tax advantages, the OECD has proposed to add on to Article 5(4) an anti-fragmentation provision in its next update to the MTC. This will deny the application of the exceptions of Article 5(4), where complementary business activities are carried on by associated enterprises at the same location, or by the same enterprise, or by associated enterprises at different locations (OECD 2015e: 10). Thus a PE would be considered to exist if, taken together, such business activities would constitute

complementary functions that are part of a cohesive business operation (OECD 2014b: para. 31 , option $\mathrm{J}$ ). This anti-fragmentation rule is of paramount importance to developing countries that are interested in ensuring that the definition of a PE acknowledges the structure of twenty-first century business models. However, concerns still remain since the antifragmentation rule is limited to 'preparatory or auxiliary' activities related to sales and may only be effective for MNEs engaged in selling physical goods like books which can be delivered from their own warehouse in the country of sale. The anti-fragmentation rule may not be effective in dealing with sales of intangible products or services (e.g. streaming services, electronic books) by digital MNEs. Thus there is still scope for fragmentation for electronic services and dematerialised products

\subsection{Issues pertaining to preventing avoidance of PE status that may be of concern to developing countries but are not addressed by the OECD BEPS project}

In its 2014 Discussion Draft on artificial avoidance of the PE concept (OECD 2014b), the OECD Working Group considered other matters that pose BEPS challenges to the PE concept, but did not address these matters in its 2015 final report. Nevertheless, they are of concern to developing countries, and so recommendations as to how these challenges can be addressed are considered below.

\subsubsection{Insurance}

In its MTC, the OECD acknowledges that insurance (including re-insurance) raises difficult issues as regards where profits from the remuneration of risk should be taxed (OECD 2014b: 40). Paragraph 39 of the OECD Commentary on Article 5 notes that an insurance company from one state can create a PE in another state, if it has a fixed place of business in that state in terms of Article 5(1), or if it carries on business through a dependent agent in terms of Article 5(5). However, agencies of foreign insurance companies sometimes do not meet either of the above requirements, and yet they can do large-scale business in a state without being taxed in that state on profits arising from such business. ${ }^{92}$ To address this challenge, paragraph 39 of the OECD Commentary on Article 5 merely provides that OECD member countries can include a provision in their double taxation agreements (DTAs) which stipulates that a state's insurance companies are deemed to have a PE in the other state if they collect premiums or insure risk in that other state through an agent established there (excluding the collection of insurance premiums or re-insurance of risk by a dependent agent who already constitutes a PE under Article 5(5)). The OECD left the decision to include such a provision in a DTA to its member countries, noting that such a provision would not be frequently needed. ${ }^{93}$ However, this matter is of concern to developing countries, but their lack of strong treaty negotiating capacity may result in them not being successful in negotiating such a provision in their DTAs. ATAF has for instance indicated that African countries have

\footnotetext{
Para. 39 of the Commentary on Article 5.
}

Ibid. 
concerns about significant insurance premiums being paid by MNEs to affiliate captive insurance companies in tax haven-jurisdictions. ${ }^{94}$ Unlike the OECD MTC, the UN MTC has Article 5(6) which specifically states that an insurance enterprise shall be deemed to have a $\mathrm{PE}$ in the other contracting state if it collects premiums or insures risks in the other state through a dependent agent. This article does not require the insurance activities to occur through a fixed place of business or for any minimum period of time (UN 2015a: 66). The only requirement is that the collection of premiums or insurance of risks should take place in the source country. Given the ease with which MNEs may alter their business structures to obtain tax advantages (OECD 2014b: 40), it would be in the interest of African countries to negotiate such a UN provision in their tax treaties to prevent BEPS arising from insurance business.

\subsubsection{Abusing PE status - concerns about subsidiary 'entity isolation'}

Another aspect of the PE definition that encourages BEPS is Article 5(7) which states that a subsidiary company in the other contracting state does not, of itself, constitute a PE of its parent company, since a subsidiary is a separate legal entity. It should be noted that this provision is subject to Article 5(1), in that a parent company may create a PE in the state of the subsidiary, if it has space at its disposal in the subsidiary's place of business and if all the other requirements of Article 5 are met. ${ }^{95}$ Also in terms of Article 5(5), if a subsidiary habitually exercises authority to conclude contracts in the name of the parent company (as a dependent agent), the parent company is deemed to have a PE in that state if all the other requirements of Article 5 are met ${ }^{96}$ Despite these provisions, the tax administrations of many African countries may not have the necessary information-gathering resources to discover the facts required to show that a PE has been created (UN 2015a: 40).

The other concern is that Article 5(7) is irrelevant to twenty-first century business models since it bolsters the OECD's notion of 'entity isolation', which fails to admit that subsidiaries in modern MNEs do not operate as separate entities but as a single unified enterprise (AviYonah and Clausing 2008). The very essence of a MNE is to ensure integration so as to encourage synergy within the group as a whole. Because the OECD encourages the separate entity notion, a MNE can assign all the activities and property that it needs to conduct business in a particular country to a separately incorporated affiliate and escape PE status by making sure that all valuable intangible property (such as patents) and activities that could generate substantial profits are not assigned to the affiliate (Mclntyre 2015: 5). The intangible property could be kept in an offshore affiliate, and then the separately incorporated affiliate in the source country would be required to pay royalties to the offshore affiliate for the use of the intangible property in the source state. In that way, the MNE would be able to limit the profits taxable in the source state (Mclntyre 2015: 5). It is disappointing that the OECD chose not to address this matter which runs at the centre of BEPS issues, since the supposed independence of MNE affiliates does not correspond to how MNEs operate. The BEPS Monitoring Group (BEPS Monitoring Group 2015: 9) points out that it would be beneficial if the OECD considered a recommendation that Article 5(7) be amended to provide that any affiliate of a MNE will be treated as having created a PE if it carries on activities which constitute complementary functions that are part of a cohesive business operation which would be in line with the anti-fragmentation rule that it recommends. 


\subsection{Preventing avoidance of PE status: Issues to be addressed post-2015}

\subsubsection{Artificial avoidance of PE status in the digital economy}

The application of the PE concept faces challenges as a result of developments in the digital economy, since the concept is based on physical presence as the primary basis for taxation. The OECD BEPS Report on the digital economy notes that 'nowadays it is possible to be heavily involved in the economic life of another country', e.g. by doing business with customers located in that country via the internet, without having a taxable presence therein (such as a substantial physical presence or a dependent agent) (OECD 2015f para. 256). Digital enterprises have for instance replaced distribution structures that previously used a local sales office, with a website selling the product for direct delivery, thus eliminating all the sales income from the domestic tax base. Similarly, services that were offered by local presence through an office can now be performed offshore and offered electronically. Thus clearly the current definition of the PE concept is ineffective in curbing BEPS in the digital economy. The concept was developed decades ago and does not encompass how business is conducted using current business models. With the digital economy, companies are increasingly supplying services rather than physical products only. The physical presence time limits of 12 or six months under the existing PE concept (in the OECD and UN MTCs consecutively) are irrelevant in determining a PE since with a click of the mouse services can be effected in the source state without physical presence there. With respect to dependency agency PE, it is possible to conclude contracts remotely through technological means, with no involvement of individual employees or dependent agents. This raises concerns about whether the existing agency PE rule, which focuses on the conclusion of contracts by dependent agents, is still appropriate (OECD $2015 f$ para. 256). The exclusions to the PE concept can also be easily manipulated in the digital economy. Activities which were previously considered to be preparatory or auxiliary activities (and hence benefit from the exceptions to the definition of PE) may increasingly be significant and core components of businesses in the digital economy (OECD $2015 f$ para. 260). For example, Article 5(4)(a), which excludes storage and delivery from the PE concept, is a major BEPS concern as the use of delivery warehouses is a large part of MNE digital companies, whose business models often rely on maintaining extensive inventory in the target country. Delivery of products or inventory to customers is often effected from a local warehouse that is not under its control and which has no employees of its own in the country of the customers. Based on the current definition of a PE under the OECD Model, this would not constitute a PE as the warehouse would be considered as used for storage purposes. In terms of the UN Model, even if there is no or little activity in the warehouse from which delivery is done, and even if the digital company maintains no employees of its own in the country of the customers, the delivery carried out from the warehouse would constitute a PE. With respect to Article $5(4)(d)$, which excludes from the PE concept the maintenance of a fixed place of business solely for the purpose of collecting information for the enterprise, companies dealing in electronic products, such as Google, can collect data about consumer preferences from a market jurisdiction by monitoring digital traffic and then selling that data to third party advertisers in other countries, thereby ensuring targeted advertisements in their marketing strategies (UN 2015a: 20). Revenues collected from advertisements to targeted users in one country can then be funnelled through subsidiaries in low tax jurisdictions, thus avoiding PE status in the country where products or services are advertised. ${ }^{97}$ These matters are of particular concern to developing countries, where there has been a significant expansion of access to digital services and increased use of technology to exploit the local market. When the OECD released its 2015 Final Reports on BEPS, it noted that work on the digital economy would only be completed in the coming years, so some of its recommendations (set out below) on the challenges raised above have not yet been finalised.

97 Johnston, S. S., 'News analysis: Chasing Google -- The Global Struggle to Tax Ecommerce', Tax Notes International, 10 February 2014, www.taxnotes.com/tax-notes-international/2014-02-10 (accessed 30 November 2016). 
OECD recommendation on addressing the tax challenges of the digital economy: The OECD suggests that where digital business models manipulate the exceptions to the PE concept in that activities which were previously considered preparatory or auxiliary may be the core components of their business - Article 5(4) of the OECD MTC will be amended to rein in these activities by ensuring (as discussed above) that all the exceptions to the PE are modified to ensure that they are available only for activities that are genuinely of a preparatory or auxiliary nature (OECD 2015f).

The OECD's options for taxing the digital economy: The OECD has come up with three options to tax digital transactions (not yet finalised) which can be applied individually or in combination.

(a) Nexus based on the concept of significant economic presence: This option would create a taxable presence in a country when a non-resident enterprise has significant economic presence in a country, on the basis of factors that evidence a purposeful and sustained interaction with the economy of that country via technology and other automated tools (OECD 2015f para. 280).

(b) A withholding tax on digital transactions: The withholding tax could be imposed as a standalone gross-basis final withholding tax on certain payments made to non-resident providers of goods and services ordered online or, alternatively, as a primary collection mechanism and enforcement tool to support the application of the nexus option described above (OECD $2015 f$ para. 292).

(c) An equalisation levy: In order to provide clarity, certainty and equity to all stakeholders, and to avoid undue burden on small and medium-sized businesses, the equalisation levy would be applied only in cases where it is determined that a non-resident enterprise has a significant economic presence (OECD $2015 f$ para. 302).

\subsubsection{Attribution of profits to PEs}

The OECD notes that BEPS concerns regarding the PE concept cannot be addressed successfully without coordinating the work on PE status with work on other actions, in particular Action 10, which deals with transfer pricing of high risk transactions. The Action 10 concern with respect to transfer pricing of high risk transactions that is pertinent with respect to PEs is base eroding head office expenses (OECD 2013b: 20). Since a PE is considered as part of its head office and not a separate legal entity, Article 7(1) of the OECD MTC requires that only profits attributable to a $P E$ are taxable in the source state. The current version of Article 7(2) (introduced in the 2010 update to the MTC) sets out the OECD authorised approach of attributing profits to a PE and how its expenses are to be treated. In terms of this approach, profits are attributed to a PE in its dealings with other parts of the enterprise as 'if it were a separate and independent enterprise' dealing with an entirely separate enterprise under conditions and at prices prevailing in the ordinary market; taking into account the functions performed, assets used and risks assumed by the enterprise through the PE and through the other parts of the enterprise. This approach is absurd because a PE is part of its head office so it is not possible for contractual allocation of risks to take place within the same entity. Since the fiction requires that a PE is treated as a separate independent entity, the OECD recommends that the arm's length principle, as set out in Article 9(1) of the OECD MTC and used to prevent transfer pricing among separate legal entities, should also apply to dealings between a PE and its head office. However this 'functionally separate entity' approach of attributing profits to a PE recognises its internal dealings with the head office by pricing them on an arm's length basis, without regard to the actual profits of the enterprise of which the PE is a part. This implies that non-actual management expenses, notional interest and royalties from the head office may be charged 
on the PE. This approach differs from the 2008 version of Article 7(3) of the OECD MTC and the approach in the UN MTC, which applies the 'single entity' approach to attribute profits to a PE and clearly denies the deduction of notional expenses, such that only the actual income and expenses of the PE are allocated. It is argued that the OECD 'functionally separate entity' approach may result in exploitation since it allows deductions for notional internal payments that exceed expenses actually incurred by the taxpayer ${ }^{98}$ Consequently many countries ${ }^{99}$ have not adopted the OECD's authorised approach due to concerns that it would result in tax revenue loss, particularly through allowing financial services businesses deductions for notional payments on internal loans and derivatives involving PEs. ${ }^{100}$ African countries are also very sceptical about adopting the OECD's approach, since MNEs often try to avoid taxes levied on the PE by claiming deductions of various forms of fees charged to the headquarter office on the PE. South Africa has for instance reserved the right to use the version of Article 7 of the OECD MTC from prior to the 2010 update, in that when applying the arm's length principle to attribute profits to a PE, notional charges or expenses are not accepted. A number of African countries' domestic tax laws also deny or limit the deductions for such fees and other expenses, such as advertising and interest (Holland and Vann 1989: Ch. 19, VII (C). The OECD BEPS Project has not yet dealt with this issue. It is hoped that the 'authorised approach' will be reconsidered.

It should be noted that under the UN MTC, in addition to attributing profits to PE, a limited force of attraction also applies which allows the source country to also tax profits derived from sales of goods and merchandise and from other business activities similar to those made or carried on through the PE if the sales or activities take place in the source country, even though such income was clearly not attributable to that PE. ${ }^{101}$ At present, this limited force of attraction rule, which is intended to function as an anti-avoidance rule, is included in only about 10 per cent of all DTAs internationally (UN 2015a: 64). The general force of attraction approach has been rejected in international tax treaty practice on the reasoning that the organisation of modern business is highly complex and that there are many companies engaged in a wide diversity of business activities in many countries. ${ }^{102} \mathrm{~A}$ company may set up a PE in a country and carry out manufacturing activities through this $\mathrm{PE}$, while a different part of the same company sells different goods or manufactures in that country through independent agents. That company may have perfectly valid commercial reasons (and not tax reasons) for doing so, for example based on the historical pattern of its business or on commercial convenience. If the country in which the PE is situated were to tax the profit of each of the transactions carried on through independent agents, with a view to aggregating that profit with the profits of the PE, this would interfere with ordinary commercial activities and would be contrary to the aims of the UN MTC. ${ }^{103}$

Attributing profits to PEs in the digital economy: Challenges of attributing profits to PE are exacerbated by the digitalisation of the economy which has resulted in dematerialisation of production, the fragmentation of functions, the creation of supply chains and the shift to

98 Deloitte 'New ATO paper on profit allocation to bank branches', newsletters.usdbriefs.com/2011/Tax/ALS/a111010_6.pdf (accessed 16 December 2016).

99 The UN Committee of Experts on International Cooperation in Tax Matters has not viewed changes as relevant to the United Nations Model Tax Convention. Some OECD countries have entered reservations to the OECD authorised approach. In the OECD MTC, para. 95 of the Commentary on Article 7 states that New Zealand reserves the right to use the previous version of Article 7 immediately before the 2010 update of the OECD MTC, because it does not agree with the approach reflected in Part 1 of the 2010 Report Attribution of Profits to Permanent Establishments. New Zealand does not, therefore, endorse the changes to the Commentary on the Article made through that update. In para 97 of the Commentary on Article 7 of the OECD MTC, Portugal reserves its right to continue to adopt in its conventions the text of the Article as it read before 2010, until its domestic law is adapted in order to apply the new approach. In para. 96 of the Commentary on Article 7 of the OECD MTC, Chile, Greece, Mexico and Turkey reserve the right to use the previous version of Article 7, before the 2010 update of the MTC. They do not, therefore, endorse the changes to the Commentary on the Article made through that update. Deloitte 'Transfer pricing law reforms' (2013), www2.deloitte.com/au/en/pages/tax/articles/transfer-pricing-lawreforms.html (accessed 16 December 2016).

Para. 10 of the 2008 Commentary on Article 7 of the OECD MTC.

Ibid.

Ibid. 
services. Where internet-based companies pay little or no tax on profits from delivery of goods or services in countries where they have large sales, this implies that profits can be attributed to affiliates in countries where they are lightly taxed.

To address these concerns, the OECD proposes that when its (above mentioned) nexus based on significant economic presence to tax digital economy is adopted, the rules for attribution of profits for the digital economy will have to be changed to suit this nexus, while ensuring parity between traditional enterprises that are subject to tax using the PE physical presence test (OECD 2015f: para. 284). In this regard, the OECD has come up with the following alternative suggestions of attributing of profits to PE (OECD 2015f: para. 285):

(a) Methods based on fractional apportionment: The OECD considered the approach of apportioning the profits of the whole enterprise to the digital presence either on the basis of a predetermined formula, or on the basis of variable allocation factors determined on a caseby-case basis. The OECD noted that in the context of a nexus based on significant economic presence, the implementation of a fractional apportionment would require: the definition of the tax base to be divided, the determination of the allocation keys to divide that tax base, and the weighting of these allocation keys, which would all be complicated to determine. The OECD noted that since the domestic laws of most countries use profit attribution methods based on the separate accounts of the PE, rather than fractional apportionment, consideration of the fractional apportionment method would not pursued further (OECD 2015f: para. 287-288).

(b)The modified deemed profit method: In the context of a nexus based on significant economic presence, the OECD notes that one possible approach would be to regard the presence to be equivalent to a physical presence from which the non-resident enterprise is operating a commercial business, and to determine the deemed net income by applying a ratio of presumed expenses to the non-resident enterprise's revenue derived from transactions concluded with customers in the country (OECD 2015f: para. 290-91).

\subsubsection{General recommendations to prevent artificial avoidance of PE status}

Apart from addressing issues pertaining to abuse of PE status, tax administrations in Africa should take note that they will not be able to prevent the ensuing tax base erosion unless they are able to identify when a non-resident is conducting a business activity within their territory. African countries should have rules that ensure early detection of PEs and they should know how to react in order to tax economic activity carried on within the source state. In this regard, the UN recommends that developing countries could emulate India, which in 2012 introduced annual reporting obligations for liaison offices to report activities of foreign entities and other entities of the same group operating in India. The UN recommends that developing countries should consider establishing this obligation with regard to foreign entities with a fixed place of business within their territory that claim the benefits of Article 5(4) (UN 2015a: 404). The UN also recommends that countries could use the withholding tax mechanism for targeted sectors (such as construction and services) (UN 2015a: 404). For example, section 107(4) of Ghana's Income Tax 896 of 2015 provides that a Ghanaian PE (which is treated as a separate entity from its owner) is required to withhold from tax any payment it makes just as a resident company would, and it is required to pay it over to the revenue authority. The UN also calls on developing countries to make use of the country-bycountry reporting mechanism under Action 13 of the OECD Action Plan on BEPS, which can be a risk-management tool for developing countries to find out if PEs have been created in their countries (OECD 2015a: 405). For African countries to benefit from country-by-country reporting, they should enact domestic legislation to enable this. For example, in South Africa, the Tax Administration Act 28 of 2011 was amended in $2015^{104}$ by the insertion in section 1

104 Amended by the Tax Administration Laws Amendment Act 23 of 2015. 
of the Act the definition 'international tax standard' to include country-by-country reporting as a standard for MNEs.

\section{General conclusion}

The discussion above has analysed how African countries can adopt the OECD's measures to curtail BEPS with respect to Actions 4, 6 and 7. The measures will give countries the tools they need to ensure that profits are taxed where the economic activities generating the profits are performed and where value is created, while giving business greater certainty. The measures will apply once they are implemented, either in domestic laws or in the network of bilateral tax treaties.

With respect to Action 4, Section 1 of this paper has discussed the best practices that the OECD recommends as more effective in limiting base erosion via interest deductions and other financial payments. The OECD hopes that such best practices will in future result in a convergence of national practices that could become minimum standards for countries to follow. As discussed in section 1, many African countries are already following certain approaches to limit base eroding interest deductions. Each country has to consider the pros and cons of its current approaches and evaluate its ability to implement the OECD's recommended best practices in light of its administrative capability. African countries also have to ensure that they balance the need to protect their tax bases with the need to attract foreign direct investment (FDI). For capital importing countries, very tight interest limitation rules may impact on the cost of borrowing for financing investments.

With respect to Action 6 on preventing treaty abuse; the OECD recommends that countries adopt certain minimum standards, because lack of action by some countries would create negative spillovers on other countries. As discussed in Section 2 above, these minimum standards will result in certain changes to the OECD MTC. Since many African countries have signed treaties based on the OECD MTC, it would be in their interest to consider adopting the minimum standards intended to prevent treaty shopping in a comprehensive and coordinated manner. The OECD does acknowledge that some of its recommendations may not be appropriate for all countries (OECD 2015c: para. 21). Customised approaches may have to be adopted in some African countries whose administrative capacity may prevent them from applying complex anti-abuse rules like the LOB test, and require them to adopt more general anti-abuse provisions (for example the PPT rule).

With respect to Action 7 on preventing the artificial avoidance of PE status, the OECD has produced guidelines to reinforce international tax standards which will result in changes to Article 5 of the OECD MTC. In order to ensure a coordinated international approach, African countries with treaties based on the OECD MTC will have to consider adopting the new international standards. It is however worth noting (as discussed in this paper) that Article 5 of the UN MTC has other provisions that are advantageous to source countries, which are not covered in the BEPS recommendations. African countries will therefore have to consider if the OECD recommendations on PEs are sufficient to ensure that they collect their fair share of taxes from the activities of MNEs in their countries. It would be in the interests of African countries to ensure that they consider not only the BEPS recommendations but also aspects of the UN MTC when negotiating Article 5 in their tax treaties. Where there is no treaty in place, African countries should also consider the appropriateness of withholding taxes in exercising their taxing rights.

Overall, protecting the tax base of African countries with respect to Actions 4, 6 and 7 will involve taking cognisance of the special needs and perspectives of the country in issue, such as the state of development of the tax system and its administrative capacity. It is advised 
that 'each country must evaluate its own situation to identify its particular issues and determine the most appropriate techniques to insure a sound tax base' (UN 2013:33). 


\section{References}

ActionAid (2012) Calling Time: Why SABMiller Should Stop Dodging Taxes in Africa, www.actionaid.org.uk/sites/default/files/doc_lib/calling_time_on_tax_avoidance.pdf (accessed 25 November 2016)

Akunobera, F. (2012) 'The Relevance of the OECD and UN Model Conventions and Their Commentaries for the Interpretation of Ugandan Tax Treaties', in Lang, M., Pistone, P., Schuch, J. and Staringer, C. (eds.) The Impact of the OECD and UN Model Tax Conventions on Bilateral Tax Treaties, Cambridge: Cambridge University Press

Arnold, B. J. (2004) 'Tax Treaties and Tax Avoidance: The 2003 Revisions to the Commentary to the OECD Model', Bulletin for International Fiscal Documentation 58: 245

Arnold, B. and McIntyre, M. (2002) International Tax Primer, Kluwer Law International

ATAF (2014) 'Outcomes Document', Consultative Conference on New Rules of the Global Tax Agenda, 18-19 March, Johannesburg, South Africa, www.slideshare.net/DrLendySpiresFoundation/outcomes-ataf-consultative-conferenceon-new-rules-of-the-global-tax-agenda (accessed 25 November 2016)

Avi-Yonah, R. S. and Clausing, K. (2008) 'Business Profits (Article 7 OECD Model Convention)' in Lang, M., Pistone, P., Schuch, J. and Staringer, C. (eds.) Source Versus Residence: Problems Arising from the Allocation of Taxing Rights in Tax Treaty Law and Possible Alternatives, Kluwer Law International

Baker, P. (2005) Double Taxation Conventions and International Law, London: Sweet \& Maxwell

BEPS Monitoring Group (2015) Overall Evaluation of the G20/OECD Base Erosion and Profit Shifting (BEPS) Project, https://bepsmonitoringgroup.files.wordpress.com/2015/10 /general-evaluation.pdf (accessed 28 November 2016)

Brooks, K. (2009) 'Tax Sparing: A Needed Incentive for Foreign Investment in Low-Income Countries or an Unnecessary Revenue Sacrifice?', Queen's Law Journal 34:2: 508

de Koker, A. (2016) Silke on South African Income Tax: Being an Exposition of the Law, Practice and Incidence of Income Tax in South Africa, Vol. 1

Easson, A. (2004) Tax Incentives for Foreign Direct Investment

Fuest, C., Hebous, S. and Riedel, N. (2011) 'International Debt Shifting and Multinational Firms in Developing Economies', Economic Letters 113: 135-138

Glenn (2014) 'Transfer Pricing and Defining the Most Challenging BEPSs Action Items, Practitioners Say', 14 February, Tax Analyst

G20 Development Working Group: Domestic Resource Mobilisation (2014) G20 Response to 2014 Reports on Base Erosion and Profit Shifting and Automatic Exchange of Information for Developing Countries, www.g20australia.org/sites/default/files/ g20_resources/library/16\%20G20\%20response\%20to\%202014\%20reports\%20on\%20 BEPS\%20and\%20AEOI\%20for\%20developing\%20economies.pdf (accessed 25 November 2016) 
Haug, S. M. (1996) 'The United States Policy of Stringent Anti-Treaty Shopping Provisions: A Comparative Analysis', Vanderbilt Journal of Trans-National Law 29: 216

Hearson, M. (2015) Tax Treaties in Sub-Saharan Africa: A Critical Review

Hines, J. R. (2001) 'Tax Sparing and Direct Investment in Developing Countries' in Hines, J.R. (ed.) International Taxation and Multinational Activity, Chicago; University of Chicago Press

Holland, D. and Vann, R. (1989) 'Income Tax Incentives for Investment' in Thuronyi, V. (ed.) Tax Law Design and Drafting: 986

Holmes, K. (2007) International Tax Policy and Double Tax Treaties: An Introduction to Principles and Application, IBFD

Huxham, K. and Haupt, P. (2015) Notes on South African Income Tax, Cape Town: Hedron

IMF (2014) Spillovers in International Corporate Taxation, www.imf.org/external/np/pp/eng/2014/050914.pdf (accessed 21 November 2016)

International Fiscal Association (2002) The OECD Model Convention - 1998 and Beyond: The Concept of Beneficial Ownership in Tax Treaties

KPMG (2013) Uganda Fiscal Guide 2012/2013

Lawrence, B. (1990) 'Government Restrictions on International Corporate Finance (Thin Capitalization)' Bulletin for International Fiscal Documentation, IBFD

Mclntyre, M. (2005) (2015) Developing Countries and International Cooperation on Income Tax Matters: A Historical View, www.michielse.com/files/mcintyre_intl_cooperation.pdf (accessed 22 November 2016)

Meyerowitz, D. (2008) Meyerowitz on Income Tax, Cape Town: Taxpayer CC

OECD (2016) Multilateral Convention to Implement Tax Treaty Related Measures to Prevent Base Erosion and Profit Shifting, Paris: OECD Publishing, www.oecd.org/tax/treaties/multilateral-convention-to-implement-tax-treaty-relatedmeasures-to-prevent-beps.htm (accessed 8 December 2016)

OECD (2015a) Explanatory Statement, Paris: OECD Publishing, www.oecd.org/ctp/bepsexplanatory-statement-2015.pdf (accessed 25 November 2016)

OECD (2015b) Limiting Base Erosion Involving Interest Deductions and Other Financial Payments, Action 4 - 2015 Final Report, Paris: OECD Publishing, www.oecdilibrary.org/taxation/limiting-base-erosion-involving-interest-deductions-and-otherfinancial-payments-action-4-2015-final-report_9789264241176-en (accessed 25 November 2016)

OECD (2015c) Preventing the Granting of Treaty Benefits in Inappropriate Circumstances, Action 6-2015 Final Report, Paris: OECD Publishing, www.oecd.org/tax/preventingthe-granting-of-treaty-benefits-in-inappropriate-circumstances-action-6-2015-finalreport-9789264241695-en.htm (accessed 25 November 2016) 
OECD (2015d) Aligning Transfer Pricing Outcomes with Value Creation, Actions 8-10 - 2015 Final Report, Paris: OECD Publishing, www.oecd.org/tax/aligning-transfer-pricingoutcomes-with-value-creation-actions-8-10-2015-final-reports-9789264241244-en.htm (accessed 29 November 2016)

OECD (2015e) Preventing the Artificial Avoidance of Permanent Establishment Status, Action 7-2015 Final Report, Paris: OECD Publishing, www.oecd.org/tax/preventingthe-artificial-avoidance-of-permanent-establishment-status-action-7-2015-final-report9789264241220-en.htm (accessed 30 November 2016)

OECD (2015f) Addressing the Tax Challenges of the Digital Economy, Action 1 - 2015 Final Report, Paris: OECD Publishing, www.oecd.org/tax/addressing-the-tax-challenges-ofthe-digital-economy-action-1-2015-final-report-9789264241046-en.htm (accessed 30 November 2016)

OECD (2014a) BEPS Action 4: Interest Deductions and Other Financial Payments, Public Discussion Draft, 18 December 2014-6 February 2015

OECD (2014b) BEPS Action 7: Preventing the Artificial Avoidance of PE Status, Public Discussion Draft, 31 October 2014-9 January 2015

OECD (2014c) Neutralising the Effects of Hybrid Mismatch Arrangements, Paris: OECD Publishing

OECD (2014d) Model Tax Convention on Income and on Capital: Condensed Version 2014, Paris: OECD Publishing, www.keepeek.com/Digital-Asset-

Management/oecd/taxation/model-tax-convention-on-income-and-on-capitalcondensed-version-2014_mtc_cond-2014-en\#page1 (accessed 16 December 2016)

OECD (2013a) Addressing Base Erosion and Profit Shifting, Paris: OECD Publishing

OECD (2013b) Action Plan on Base Erosion and Profit Shifting, Paris: OECD Publishing

OECD (2012) Thin Capitalisation Legislation: A Background Paper for Country Tax Administrators, OECD

OECD (1987) Issues in International Taxation No.2: Thin Capitalisation: Taxation of Entertainers, Artists and Sportsmen, Paris: OECD Publications

OECD Committee on Fiscal Affairs (1987) Double Taxation Conventions and the Use of Conduit Companies, OECD

Oguttu, A.W. (2016) Tax Base Erosion and Profit Shifting in Africa - Part 1: What Should Africa's Response Be to the OECD BEPS Action Plan? ICTD Working Paper 54, Brighton: ICTD ${ }^{105}$

Oguttu, A, W. (2015) 'Tax Base Erosion and Profit Shifting in Africa - Part 1: What Should Africa's Response Be to the OECD BEPS Action Plan?' The Comparative and International Law Journal of Southern Africa, XLVIII: 516-552

Oguttu, A.W. (2015) International Tax Law: Offshore Tax Avoidance in South Africa, Juta and Co.

\footnotetext{
${ }^{105}$ Oguttu 2016 and Oguttu 2015 are the same paper, published by two different publishers.
} 
Oguttu, A. W (2014) 'A Critique on the Effectiveness of 'Exchange of Information on Tax Matters' in Preventing Tax Avoidance and Evasion: A South African Perspective', Bulletin for International Taxation, 68.1

Oguttu, A.W. (2013) 'Curbing Thin Capitalisation: A Comparative Overview with Specific Reference to South Africa's Approach - Challenges Posed by the Amended Section 31 of the Income Tax Act', Bulletin for International Taxation, 67.6: 312

Oguttu, A.W. (2012) 'Challenges in Taxing Derivative Financial Instruments: International Views and South Africa's Approach' South African Mercantile Law Journal, 24: 388

Oguttu, A. W. (2011) 'The Challenges of Tax Sparing: A Call to Reconsider the Policy in South Africa', Bulletin for International Taxation, 65:1

Oguttu, A. W. (2010) 'The Challenges of Taxing Profits Attributed to Permanent Establishments: A South African Perspective', Bulletin for International Taxation, 64.3: 165-175

Oguttu, A.W. (2009a) 'The Challenges of Taxing Investments in Offshore Hybrid Entities: A South African Perspective', South African Mercantile Law Journal, 21.1: 51-73

Oguttu, A. W. (2009b) 'E-commerce: A Critique on the Determination of a 'Permanent Establishment' for Income Tax Purposes from a South African Perspective, Stellenbosch Law Review 20.1: 74-96

Oguttu, A. W. (2008) 'Resolving Double Taxation: The Concept 'Place of Effective Management' Analysed from a South African Perspective', The Comparative and International Law Journal of Southern Africa XLI No. 1: 80-104

Oguttu, A.W. (2007) 'Curbing Treaty Shopping: The Beneficial Ownership Provision Analysed from a South African Perspective' The Comparative and International Law Journal of Southern Africa XL No.2: 242

Oguttu, A. W. (2006) 'Transfer Pricing and Tax Avoidance: Is the Arm's Length Principle Still Relevant in the E-commerce Era?' South African Mercantile Law Journal, 18.2: 39

Oleynic, I. (2006) Mauritius Tax Guide

Olivier, L. and Honiball, B. (2011) International Tax: A South African Perspective, Cape Town: Siber Ink

PwC, EuropeAid (2011) Transfer Pricing and Developing Countries: Final Report, PwC and EuropeAid

Reinhold, R.L. (2000) 'What is Tax Treaty Abuse? (Is Treaty Shopping an Outdated Concept?)' The Taxpayer 53:6: 673

Richardson, G. Hanlon, D. and Nethercott, L. (1998) 'Thin Capitalization: An Anglo-American Comparison' The International Tax Journal 24: 2: 36.

Rohatgi, R. (2002) Basic International Taxation

Roper, P. and Ware, J. (2001) Offshore Insight

Roper, P. and Ware, J. (2000) Offshore Pitfalls 
SARS (2013) Draft Interpretation Note: Determination of the Taxable Income of Certain Persons from International Transactions: Thin Capitalisation, South African Revenue Services

Schulze, H. C. A. W. (1997) International Tax-Free Trade Zones and Free Ports: A Comparative Study of their Principles and Practices

Sommerhalder, R. A. (1996) 'Approaches to Thin Capitalisation', Bulletin for International Fiscal Documentation, IBFD

Tax Justice Network-Africa (2015) Tax Drainage: Kenya/Mauritius DTA and its Potential Impact on Tax Base Erosion in Kenya, Tax Justice Network-Africa

Taxwise (2014) 'Double Tax Agreements and Tax Information Exchange Agreements', Tax Alert, Issue 1

Thuronyi, V. (2003) 'Recent Treaty Practice on Tax Sparing', Tax Notes International 29:301

Tomsett, E. (1989) Tax Planning for Multinational Companies, New York: WoodheadFaulkner

United Nations (2015a) Handbook on Selected Issues in Protecting the Tax Base of Developing Countries, New York: United Nations, www.un.org/esa/ffd/wpcontent/uploads/2015/07/handbook-tb.pdf (accessed 25 November 2016)

United Nations (2015b) 'Outcome document of the Third International Conference on Financing for Development: Addis Ababa Action Agenda', Addis Ababa, 13-16 July 2015, www.un.org/ga/search/view_doc.asp?symbol=A/CONF.227/L.1 (accessed 25 November 2016)

United Nations (2013) Protecting the Tax Base of Developing Countries: An Overview. Papers on Selected Topics in Protecting the Tax Base of Developing Countries: Draft Paper No. 1, H.J. Ault and B.J. Arnold, www.un.org/esa/ffd/wpcontent/uploads/2014/10/20140604_Paper1_Ault.pdf (accessed 9 December 2016)

United Nations (2011) Model Double Taxation Convention between Developed and Developing Countries, New York: United Nations, www.un.org/esa/ffd/documents/ UN_Model_2011_Update.pdf (accessed 29 November 2016)

United Nations Committee of Experts on International Cooperation in Tax Matters (2014) Responses to Questionnaire for Developing Countries from the UN Subcommittee on Base Erosion and Profit Shifting, Tenth Session of UN Committee of Experts on International Cooperation in Tax Matters, 27-31 October 2014, Geneva www.un.org/esa/ffd/tax/tenthsession/CRP12_BEPS.pdf (accessed 25 November 2016)

van Weeghel, S. (1998) The Improper Use of Tax Treaties with Particular Reference to the Netherlands and The United States, Kluwer Law International

Vogel, K. (1997) Double Taxation Conventions

Wijnen, W., de Goede, J. and Alessi, A. (2012) 'The Treatment of Services in Tax Treaties' Bulletin for International Taxation, 66.1

Wurm, F. J. (1992) 'Treaty Shopping in the 1992 OECD Model Convention', Intertax: 658 


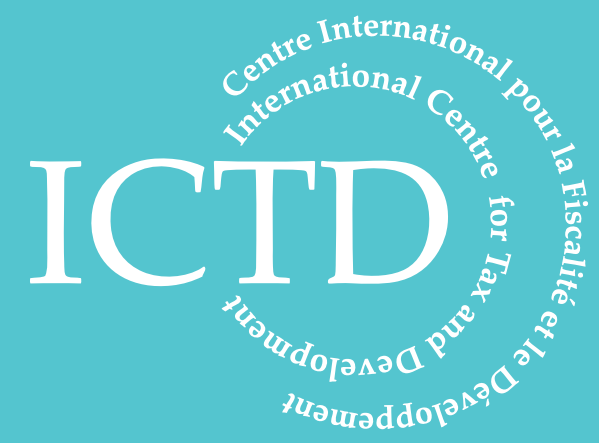

International Centre for Tax and Development at the Institute of Development Studies

Brighton BN1 9RE, UK

T: +44 (0) 1273606261

F: $+44(0) 1273621202$

E: info@ictd.ac

www.ictd.ac 